\title{
SLEETMUTE ELECTROMAGNETIC AND MAGNETIC AIRBORNE GEOPHYSICAL SURVEY DATA COMPILATION
}

L.E. Burns, G.R.C. Graham, J.D. Barefoot, Fugro Airborne Surveys, and Stevens Exploration Management Corp.

Geophysical Report 2019-16

2019

STATE OF ALASKA

DEPARTMENT OF NATURAL RESOURCES

DIVISION OF GEOLOGICAL \& GEOPHYSICAL SURVEYS
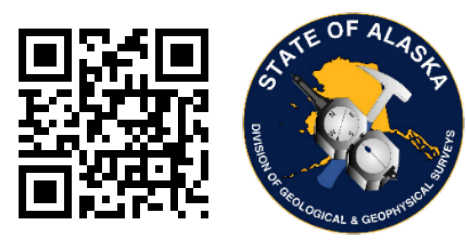
STATE OF ALASKA

Michael J. Dunleavy, Governor

DEPARTMENT OF NATURAL RESOURCES

Corri A. Feige, Commissioner

\title{
DIVISION OF GEOLOGICAL \& GEOPHYSICAL SURVEYS
}

Steve Masterman, State Geologist \& Director

Publications produced by the Division of Geological \& Geophysical Surveys are available to download from the DGGS website (dggs.alaska.gov). Publications on hard-copy or digital media can be examined or purchased in the Fairbanks office:

\author{
Alaska Division of Geological \& Geophysical Surveys (DGGS) \\ 3354 College Road | Fairbanks, Alaska 99709-3707 \\ Phone: 907.451 .5010 | Fax 907.451.5050 \\ dggspubs@alaska.gov $\mid$ dggs.alaska.gov
}

DGGS publications are also available at:

Alaska State Library, Historical

Collections \& Talking Book Center

395 Whittier Street

Juneau, Alaska 99801

Alaska Resource Library and

Information Services (ARLIS)

3150 C Street, Suite 100

Anchorage, Alaska 99503

\section{Suggested citation:}

Burns, L.E., Graham, G.R.C., Barefoot, J.D., Fugro Airborne Surveys, and Stevens Exploration Management Corp., 2019, Sleetmute electromagnetic and magnetic airborne geophysical survey data compilation: Alaska Division of Geological \& Geophysical Surveys Geophysical Report 2019-16. http://doi.org/10.14509/30223
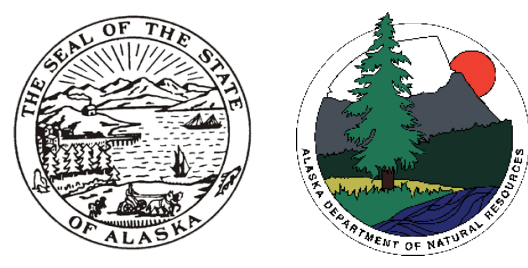


\section{SLEETMUTE ELECTROMAGNETIC AND MAGNETIC AIRBORNE GEOPHYSICAL SURVEY DATA COMPILATION \\ L.E. Burns ${ }^{1}$, G.R.C. Graham ${ }^{1}$, J.D. Barefoot ${ }^{1}$, Fugro Airborne Surveys, and Stevens Exploration Management Corp.}

\section{ABSTRACT}

Sleetmute electromagnetic and magnetic airborne geophysical survey geophysical survey is located in western Alaska in the Aniak mining district, about 270 kilometers west of Anchorage, Alaska. The survey is adjacent to the Aniak and Holitna Basin geophysical surveys. Frequency domain electromagnetic and magnetic data were collected with the DIGHEM ${ }^{\mathrm{V}}$ system in October 2002. A total of 5014.4 line kilometers were collected covering 1746.8 square kilometers. Line spacing was 400 meters (m). Data were collected 30 $\mathrm{m}$ above the ground surface from a helicopter towed sensor platform ("bird") on a $30 \mathrm{~m}$ long line.

\section{PURPOSE}

This airborne geophysical survey is part of a program to acquire data on Alaska's most promising mineral belts and districts. The information acquired is aimed at catalyzing new private-sector exploration, discovery, and ultimate development and production. The purpose of the survey was to map the magnetic and conductive properties of the survey area. Whereas the Aniak mining district has a history of placer gold mining, there are also inactive mercury mines and prospects in the area, including the Red Devil deposit. Other gold and base-metal anomalies, altered zones, favorable lithologies, and structural zones are known to exist throughout the survey area.

\section{SURVEY OVERVIEW DESCRIPTION}

This document provides an overview of the survey and includes text and figures of select primary and derivative products of this survey. A table of digital data packages available for download is provided to assist users in data selection. For reference, a catalog of the available maps is presented in reduced resolution. Please consult the metadata, project report, and digital data packages for more information and data.

\section{ACKNOWLEDGMENTS}

Funding was provided by the U.S. Department of Interior Bureau of Land Management (BLM).

\footnotetext{
${ }^{1}$ Alaska Division of Geological \& Geophysical Surveys, 3354 College Road, Fairbanks, Alaska 99709-3707
} 


\section{AVAILABLE DATA}

\begin{tabular}{|c|c|c|}
\hline Data Type & Provider & Description \\
\hline ascii_data & contractor & ASCII format line data, other ASCII data \\
\hline databases_geosoft & contractor & $\begin{array}{l}\text { Geosoft format database of final line data, other Geosoft } \\
\text { format databases }\end{array}$ \\
\hline documents & contractor and DGGS & $\begin{array}{l}\text { Project and field reports, survey background information, } \\
\text { gridded data explanations, other documentation }\end{array}$ \\
\hline grids_ermapper & contractor and DGGS & $\begin{array}{l}\text { Geographically registered gridded data, ER Mapper ERS } \\
\text { format }\end{array}$ \\
\hline grids_geosoft & contractor and DGGS & $\begin{array}{l}\text { Geosoft-format grids, these grids can be viewed in ESRI } \\
\text { ArcMap using a free plugin from Geosoft or the free viewer } \\
\text { available from Geosoft }\end{array}$ \\
\hline images_registered & DGGS & GeoTiff format images of all gridded data \\
\hline $\mathrm{kmz}$ & DGGS & $\begin{array}{l}\text { keyhole markup language }(\mathrm{kml}) \mathrm{kmz} \text { archive files of project } \\
\text { data. Viewable in Google Earth and other compatible } \\
\text { programs }\end{array}$ \\
\hline maps_pdf_format & contractor and DGGS & $\begin{array}{l}\text { Printable maps in pdf format. Includes a geographically } \\
\text { registered pdf (GeoPDF) for use with mobile devices such } \\
\text { as GPS enabled smartphones and tablets, other devices, } \\
\text { and programs }\end{array}$ \\
\hline maps_prn_format & contractor & $\begin{array}{l}\text { Printable maps in HPGL/2 printer file format with extension } \\
\text {.prn }\end{array}$ \\
\hline profiles_stacked & contractor & $\begin{array}{l}\text { Distance-based profiles of the digitally recorded } \\
\text { geophysical data are generated and plotted at an } \\
\text { appropriate scale. The profiles display electromagnetic } \\
\text { anomalies with their respective interpretive symbols. } \\
\text { Printable in pdf format }\end{array}$ \\
\hline vector_data & contractor and DGGS & $\begin{array}{l}\text { Line path, data contours, and survey boundary in ESRI } \\
\text { shapefile (SHP) format, ESRI Geodatabase format, and/or } \\
\text { AutoCAD dxf format }\end{array}$ \\
\hline video_flightpath & contractor & Survey flight path downward facing video \\
\hline
\end{tabular}




\section{REFERENCES}

Akima, H., 1970, A new method of interpolation and smooth curve fitting based on local procedures: Journal of the Association of Computing Machinery, v. 17, n. 4, p. 589-602.

Burns, L.E., U.S. Bureau of Land Management, Fugro Airborne Surveys, and Stevens Exploration Management Corp., 2003, Line, grid, and vector data of the airborne geophysical survey data of the Sleetmute area, southwestern Alaska: Alaska Division of Geological \& Geophysical Surveys Geophysical Report 2003-10, 1 DVD. http://doi.org/10.14509/2994

Burns, L.E., U.S. Bureau of Land Management, Fugro Airborne Surveys, and Stevens Exploration Management Corp., 2003, Plot files of the airborne geophysical survey data of the Sleetmute area, southwestern Alaska: Alaska Division of Geological \& Geophysical Surveys Geophysical Report 20039, 1 DVD. http://doi.org/10.14509/2976

Burns, L.E., U.S. Bureau of Land Management, Fugro Airborne Surveys, and Stevens Exploration Management Corp., 2003, Portfolio of aeromagnetic and resistivity maps of the Sleetmute area, southwestern Alaska: Alaska Division of Geological \& Geophysical Surveys Geophysical Report 200312. http://doi.org/10.14509/2996

Fraser, D.C., 1978, Resistivity mapping with an airborne multicoil electromagnetic system: Geophysics, V. 43, p. 144-172.

Stephens, Mark, and Fugro Airborne Surveys, 2003, Project report of the airborne geophysical survey of the Sleetmute area, southwestern Alaska: Alaska Division of Geological \& Geophysical Surveys Geophysical Report 2003-11, 211 p., 2 sheets, scale 1:63,360. http://doi.org/10.14509/2995 


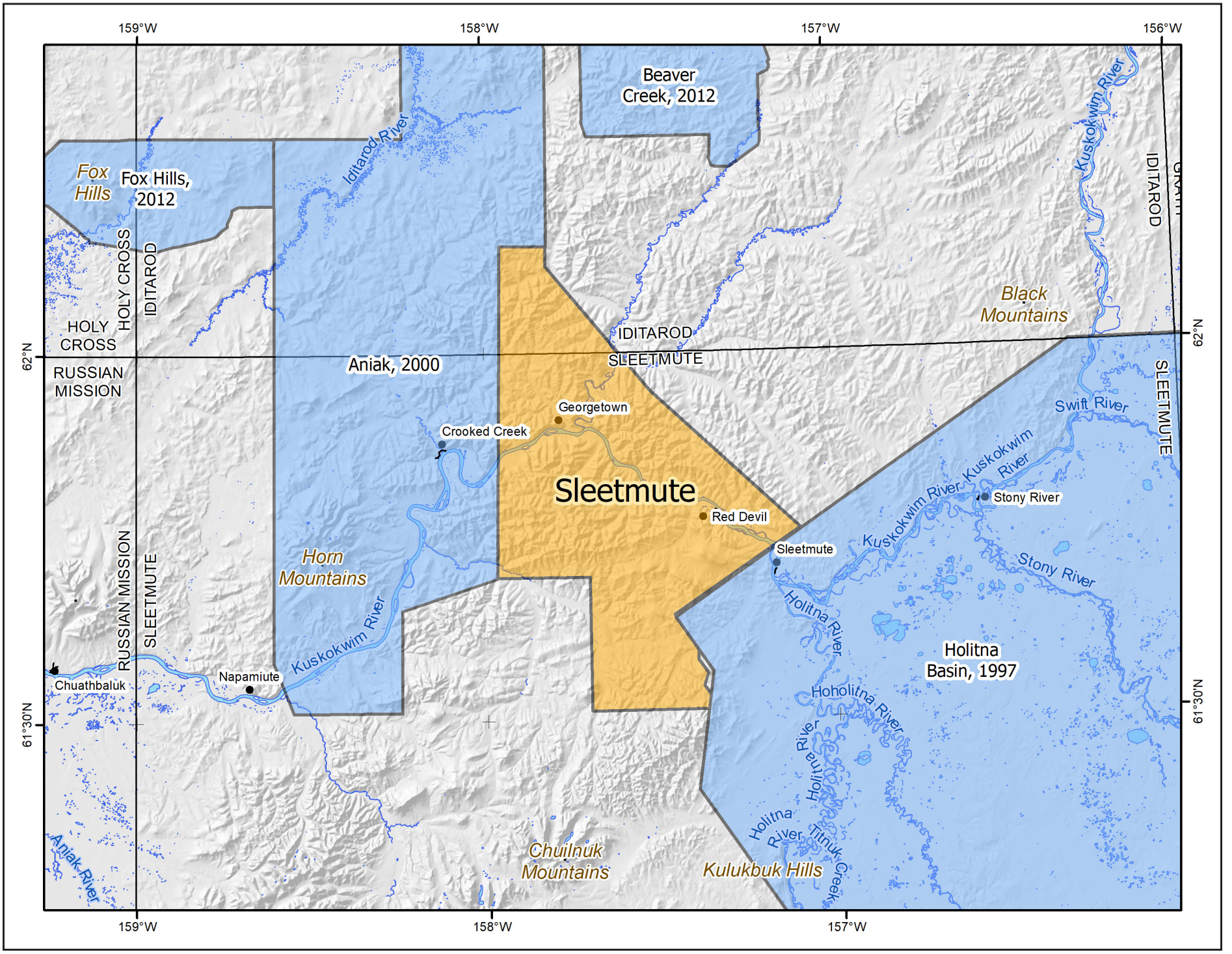

Figure 1. Sleetmute electromagnetic and magnetic airborne geophysical survey location shown in western Alaska (inset). Sleetmute survey area shown with adjacent DGGS geophysical surveys, landmarks, relevant 1:250,000-scale quadrangle boundaries, mountain ranges, rivers, glaciers, and elevation hillshade.

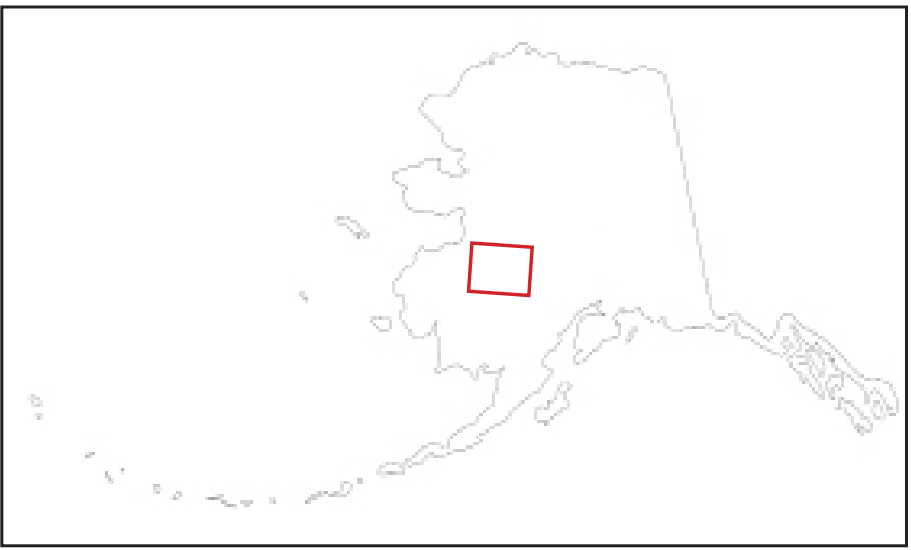




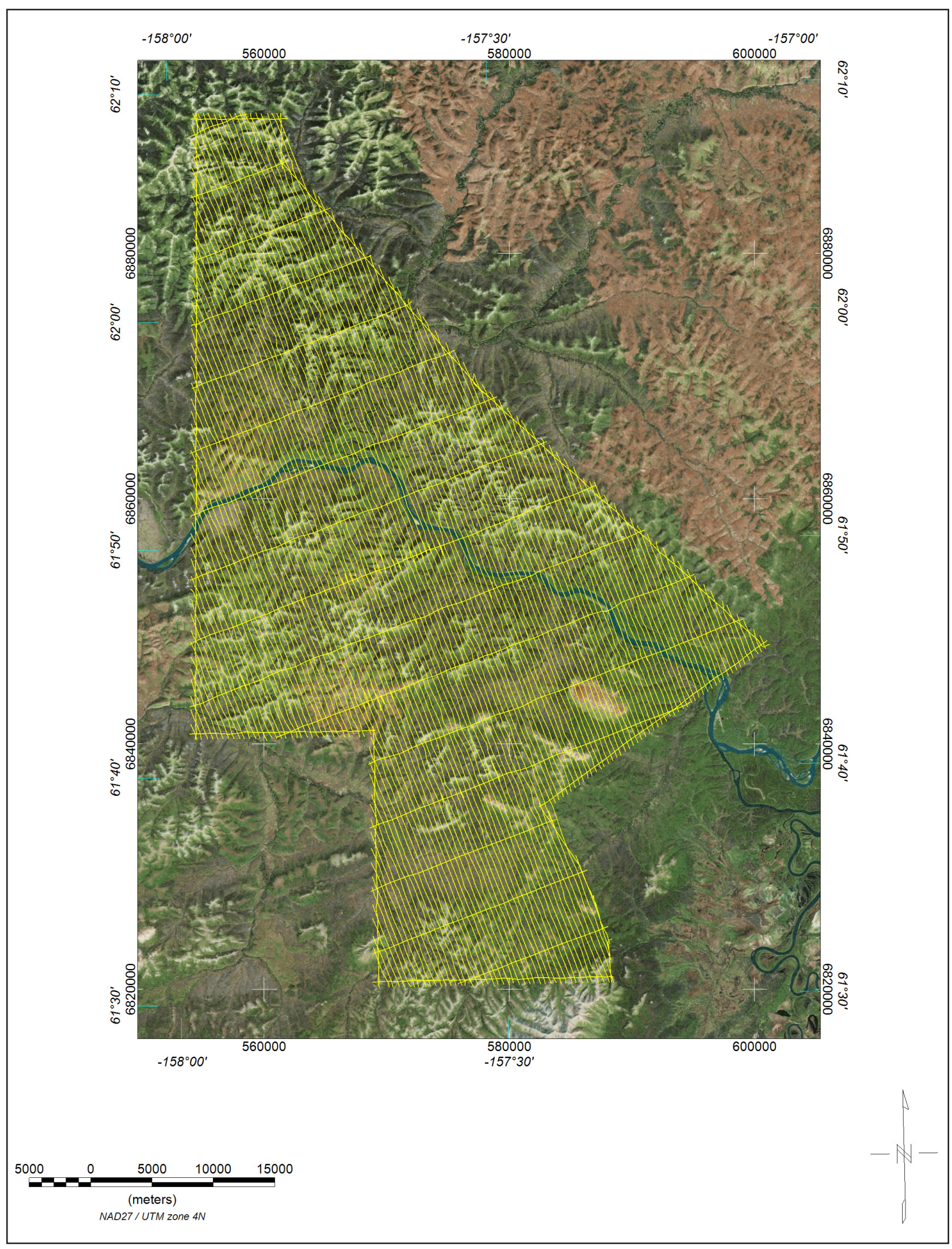

Figure 2. Flight path with orthometric image. 


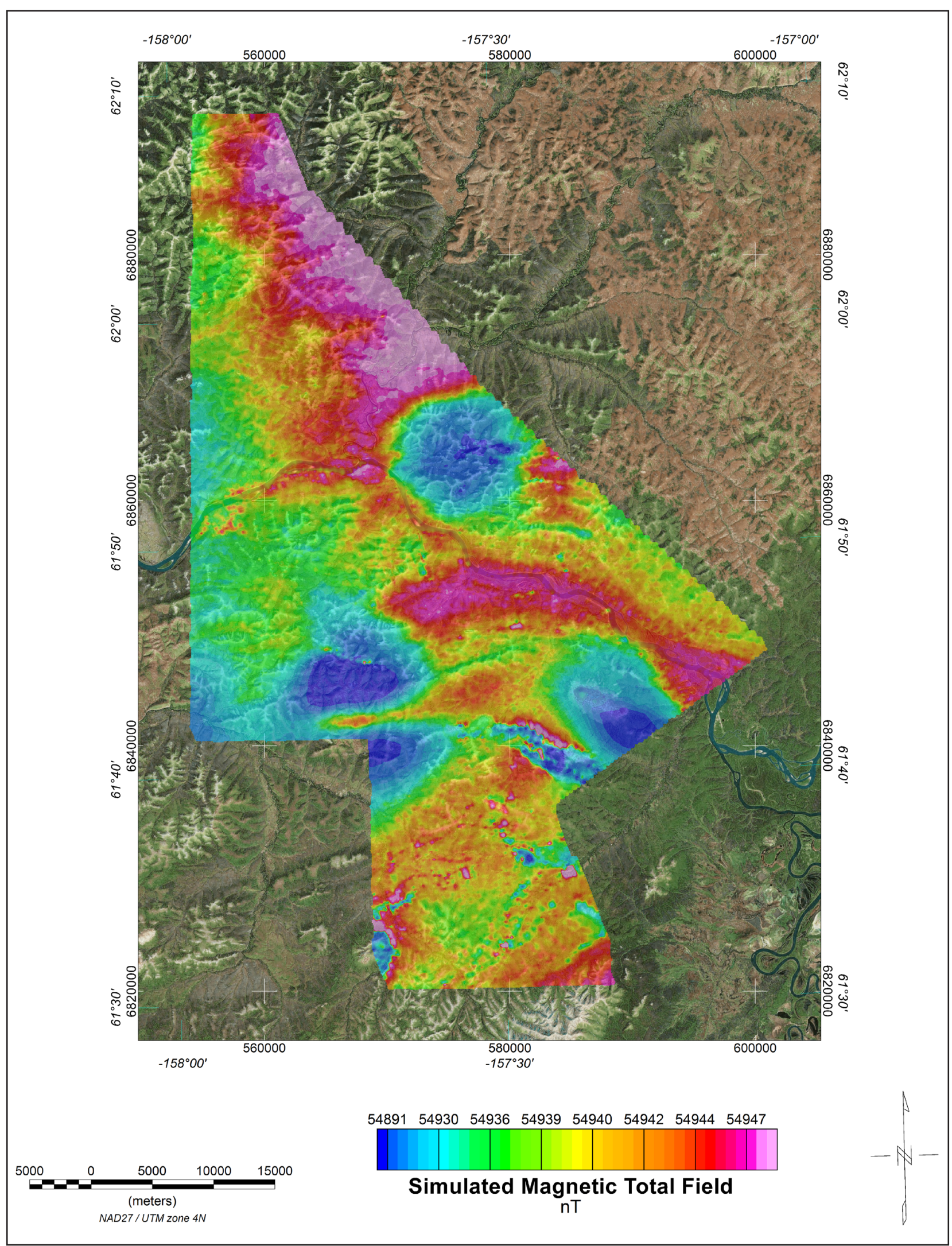

Figure 3. Simulated Magnetic Total Field Grid with orthometric image. The magnetic total field data were processed using digitally recorded data from a Scintrex cesium magnetometer. Data were collected at a sampling interval of 0.1 seconds. The magnetic data were (1) corrected for diurnal variations by subtracting the digitally recorded base station magnetic data, (2) IGRF corrected (IGRF model 2000, updated to September 2002), (3) leveled to the tie line data, (4) a constant value of approximately 55,000 nT was added to all data, and (5) interpolated onto a regular $100 \mathrm{~m}$ grid using a modified Akima (1970) technique. 


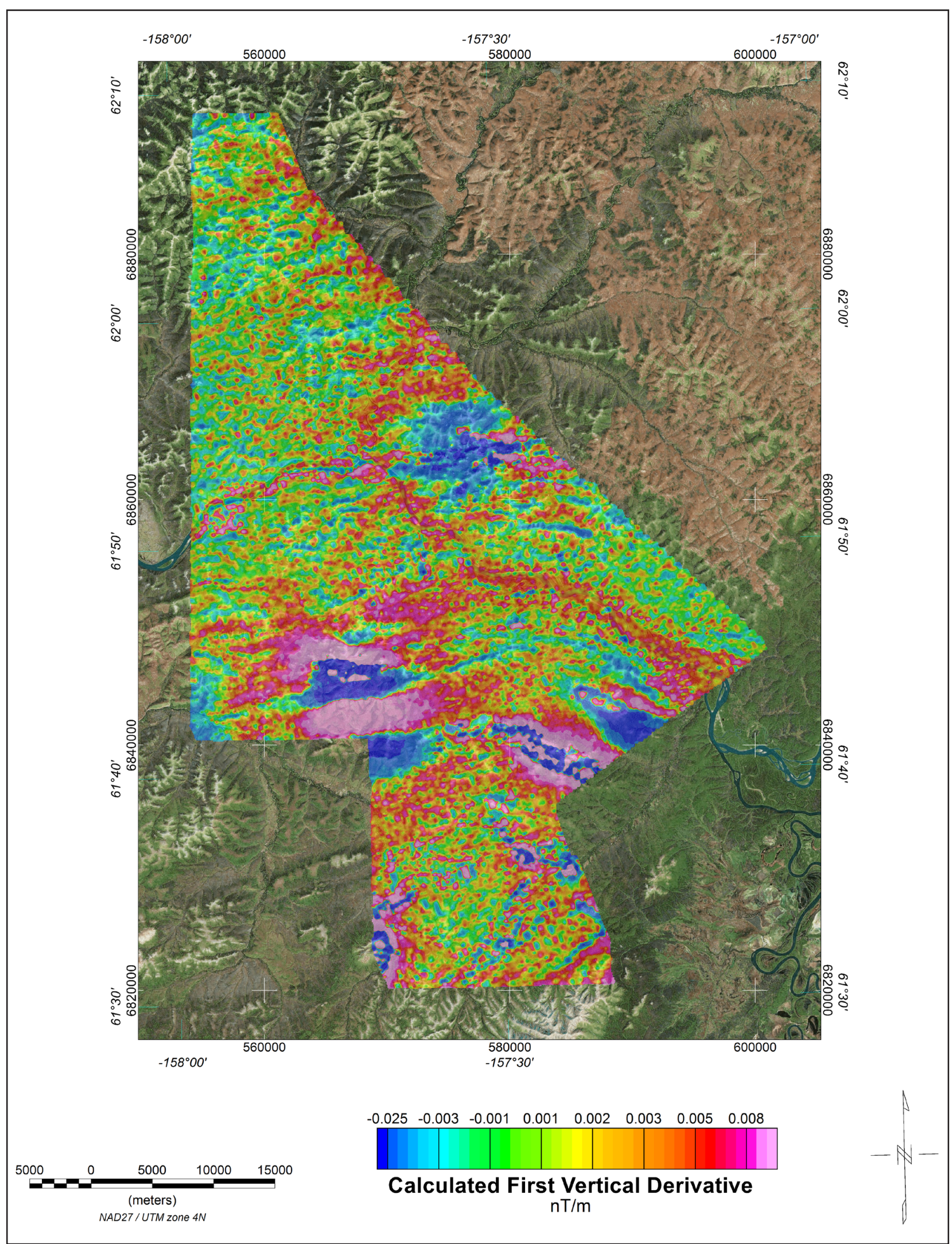

Figure 4. Calculated First Vertical Derivative Grid with orthometric image. The first vertical derivative grid was calculated from the diurnally-corrected, IGRF-corrected total magnetic field grid using a FFT base frequency domain filtering algorithm. The resulting first vertical derivative grid provides better definition and resolution of near- surface magnetic units and helps to identify weak magnetic features that may not be evident on the total field data. 


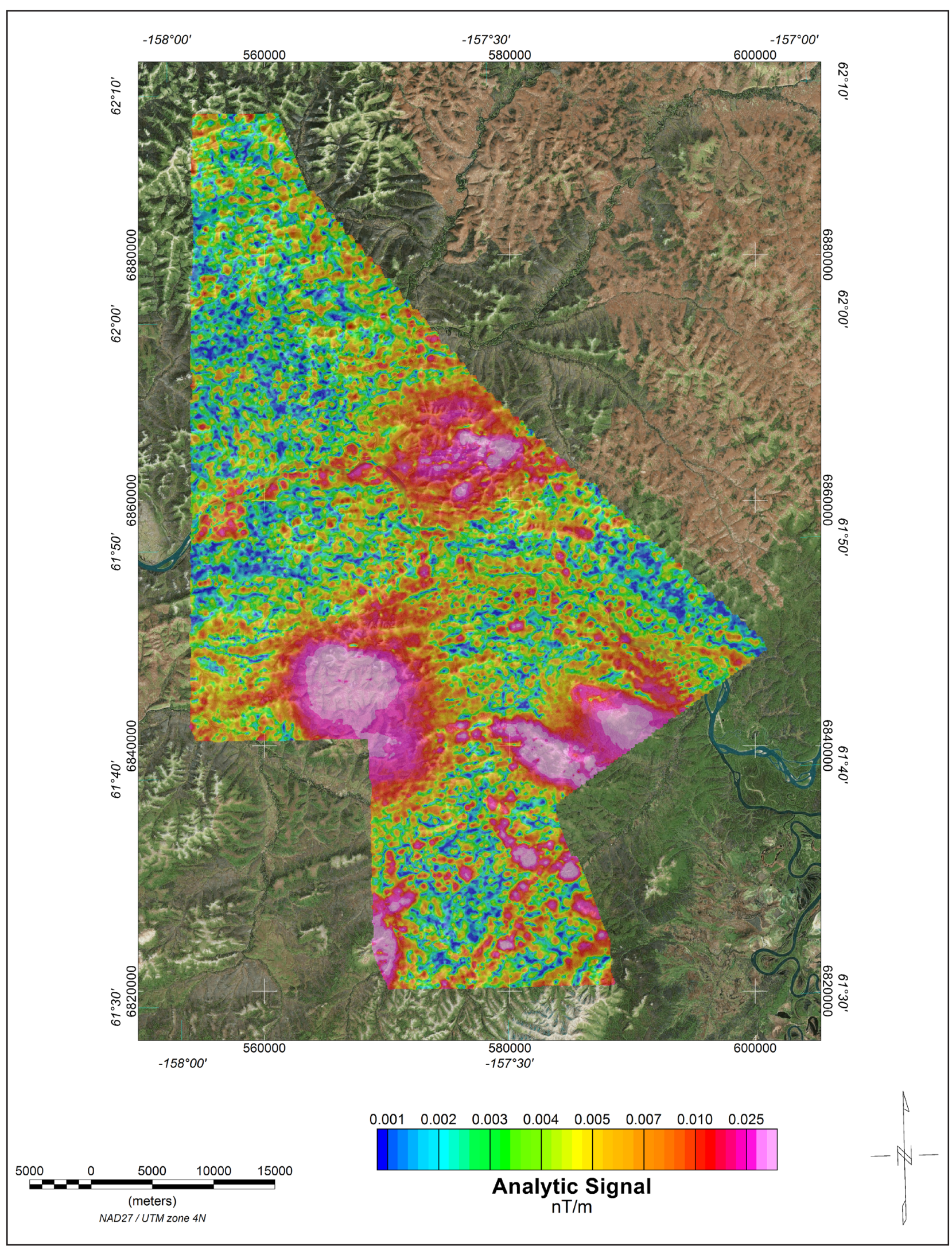

Figure 5. Analytic Signal Grid with orthometric image. Analytic signal is the total amplitude of all directions of magnetic gradient calculated from the sum of the squares of the three orthogonal gradients. Mapped highs in the calculated analytic signal of magnetic parameter locate the anomalous source body edges and corners (such as contacts, fault/shear zones, etc.). Analytic signal maxima are located directly over faults and contacts, regardless of structural dip, and independent of the direction of the induced and/or remanent magnetizations. 


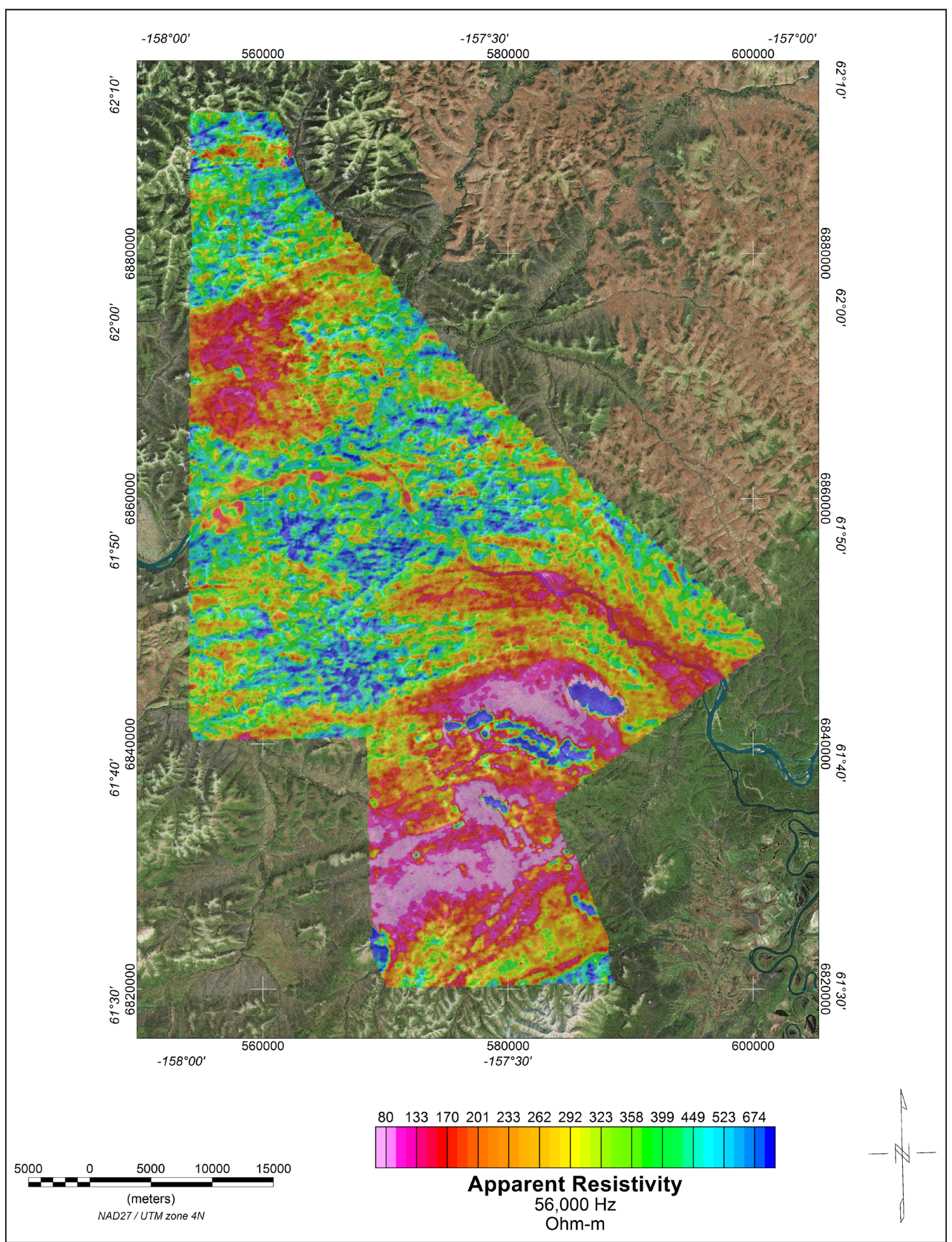

Figure 6. 56,000 Hz coplanar Apparent Resistivity Grid with orthometric image. The DIGHEMV EM system measured inphase and quadrature components at five frequencies. Two vertical coaxial coil-pairs operated at 1000 and $5500 \mathrm{~Hz}$ while three horizontal coplanar coil-pairs operated at $900,7,200$, and $56,000 \mathrm{~Hz}$. EM data were sampled at 0.1 second intervals. The EM system responds to bedrock conductors, conductive overburden, and cultural sources. Apparent resistivity is generated from the inphase and quadrature component of the coplanar $56,000 \mathrm{~Hz}$ using the pseudo-layer half space model (Fraser 1978). The data were interpolated onto a regular $100 \mathrm{~m}$ grid using a modified Akima (1970) technique. 


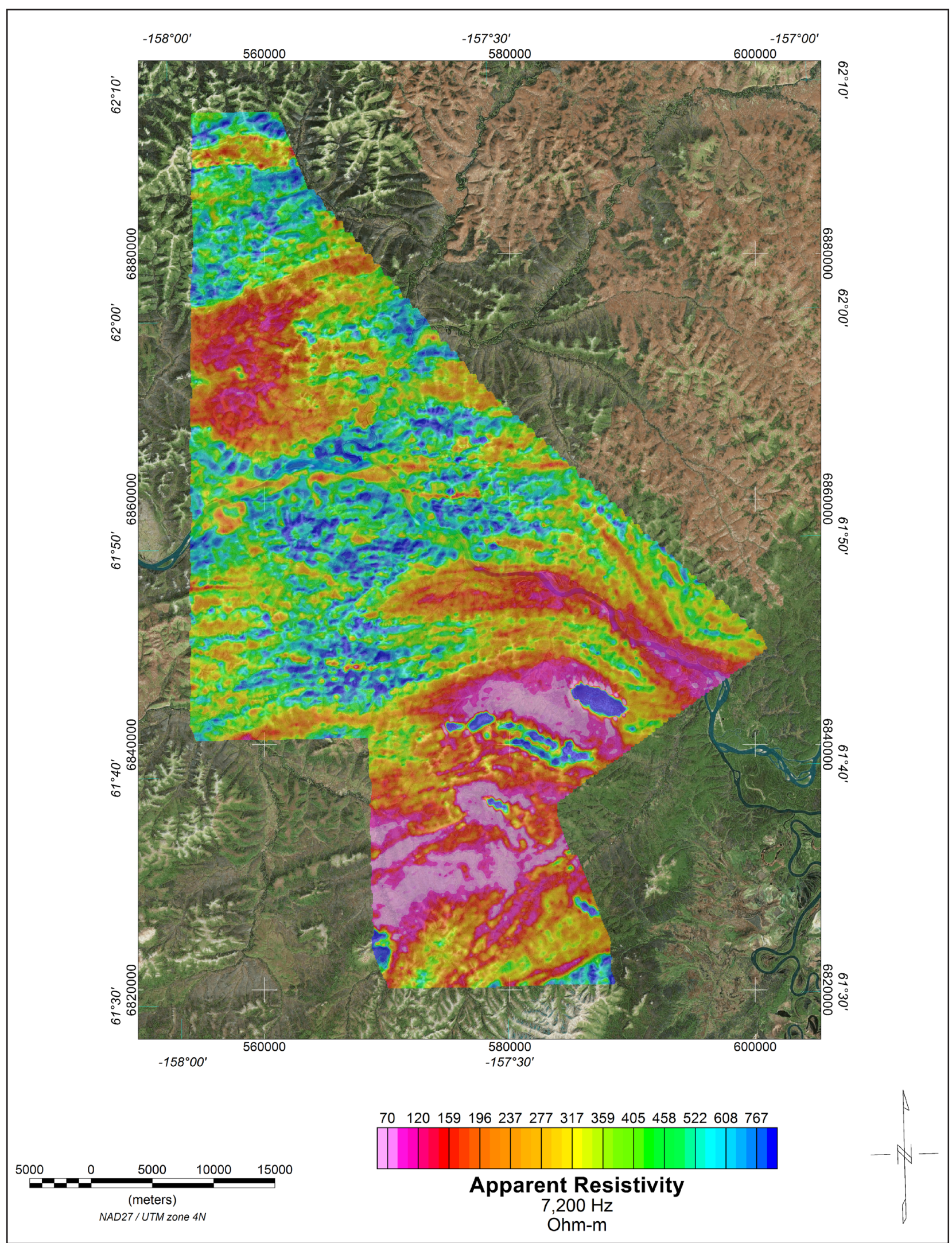

Figure 7. 7,200 Hz coplanar Apparent Resistivity Grid with orthometric image. The DIGHEM ${ }^{\vee} E M$ system measured inphase and quadrature components at five frequencies. Two vertical coaxial coil-pairs operated at 1000 and $5500 \mathrm{~Hz}$ while three horizontal coplanar coil-pairs operated at $900,7,200$, and $56,000 \mathrm{~Hz}$. EM data were sampled at 0.1 second intervals. The EM system responds to bedrock conductors, conductive overburden, and cultural sources. Apparent resistivity is generated from the inphase and quadrature component of the coplanar $7,200 \mathrm{~Hz}$ using the pseudo-layer half space model (Fraser 1978). The data were interpolated onto a regular $100 \mathrm{~m}$ grid using a modified Akima (1970) technique. 


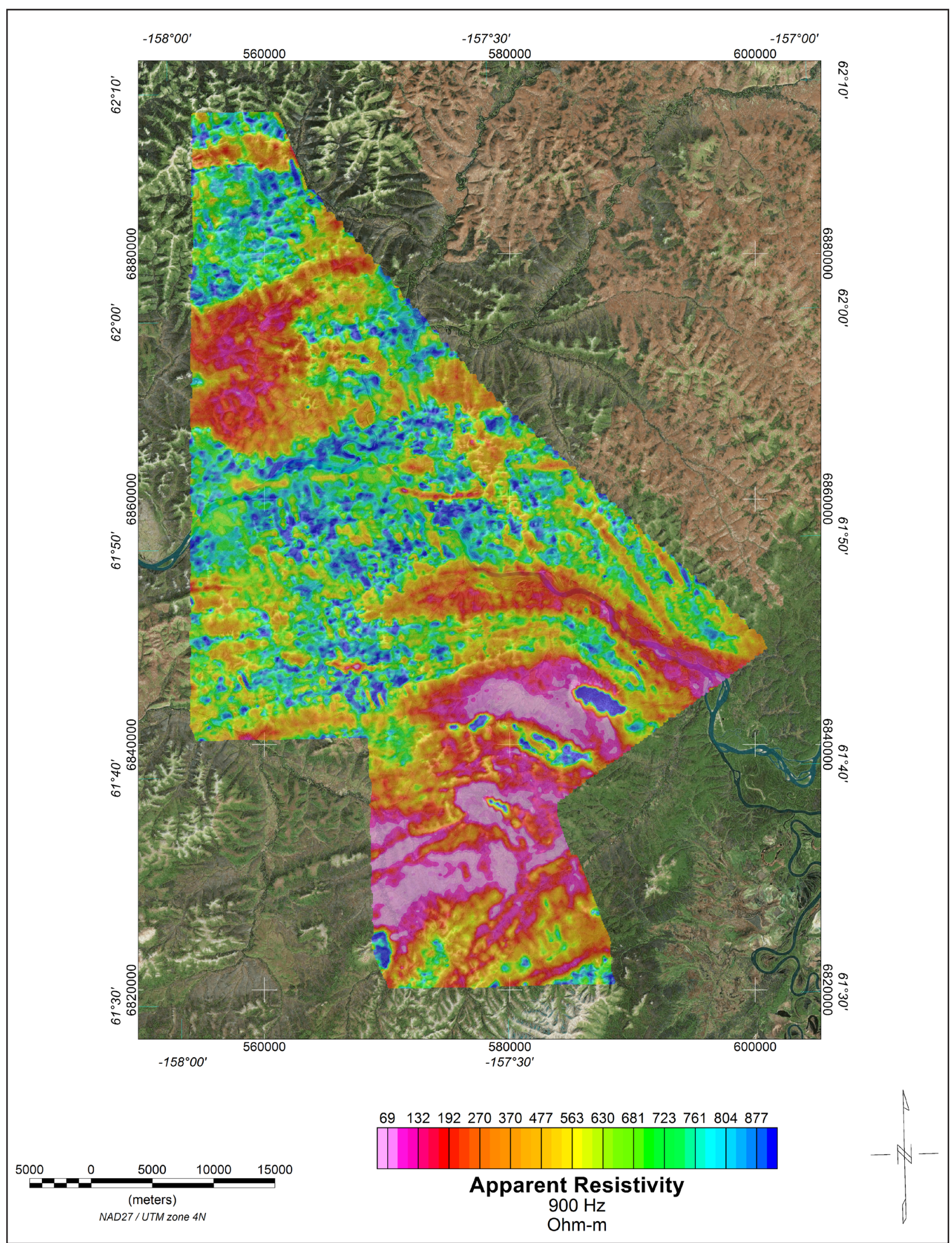

Figure 7. $900 \mathrm{~Hz}$ coplanar Apparent Resistivity Grid with orthometric image. The DIGHEMV EM system measured inphase and quadrature components at five frequencies. Two vertical coaxial coil-pairs operated at 1000 and $5500 \mathrm{~Hz}$ while three horizontal coplanar coil-pairs operated at $900,7,200$, and $56,000 \mathrm{~Hz}$. EM data were sampled at 0.1 second intervals. The EM system responds to bedrock conductors, conductive overburden, and cultural sources. Apparent resistivity is generated from the inphase and quadrature component of the coplanar $900 \mathrm{~Hz}$ using the pseudo-layer half space model (Fraser 1978). The data were interpolated onto a regular $100 \mathrm{~m}$ grid using a modified Akima (1970) technique. 
Table 1. Copies of the following maps are included at the end of this booklet. The low-resolution, page-size maps included in this booklet are intended to be used as a search tool and are not the final product. Large-scale, full-resolution versions of each map are available to download on this publication's citation page: http://doi.org/10.14509/30223.

\begin{tabular}{|c|c|}
\hline Map Title & Description \\
\hline sleetmute_sim_magtf_topo_map_1of2.pdf & simulated magnetic total field grid with topographic base map \\
\hline sleetmute_sim_magtf_topo_map_2of2.pdf & simulated magnetic total field grid with topographic base map \\
\hline $\begin{array}{l}\text { sleetmute_sim_magtf_contours_plss_map_1 of } 2 . \\
\text { pdf }\end{array}$ & $\begin{array}{l}\text { simulated magnetic total field grid and contours with public land survey } \\
\text { system base layer }\end{array}$ \\
\hline $\begin{array}{l}\text { sleetmute_sim_magtf_contours_plss_map_2of2. } \\
\text { pdf }\end{array}$ & $\begin{array}{l}\text { simulated magnetic total field grid and contours with public land survey } \\
\text { system base layer }\end{array}$ \\
\hline $\begin{array}{l}\text { sleetmute_sim_magtf_shaded_plss_map_1 of2. } \\
\text { pdf }\end{array}$ & $\begin{array}{l}\text { shaded simulated magnetic total field grid with public land survey system } \\
\text { base layer }\end{array}$ \\
\hline $\begin{array}{l}\text { sleetmute_sim_magtf_shaded_plss_map_2of2. } \\
\text { pdf }\end{array}$ & $\begin{array}{l}\text { shaded simulated magnetic total field grid with public land survey system } \\
\text { base layer }\end{array}$ \\
\hline $\begin{array}{l}\text { sleetmute_emanomalies_sim_magtf_contours_ } \\
\text { plss_map_1of2.pdf }\end{array}$ & $\begin{array}{l}\text { EM anomaly map with simulated magnetic total field grid contours and } \\
\text { public land survey system base layer }\end{array}$ \\
\hline $\begin{array}{l}\text { sleetmute_emanomalies_sim_magtf_contours_ } \\
\text { plss_map_2of2.pdf }\end{array}$ & $\begin{array}{l}\text { EM anomaly map with simulated magnetic total field grid contours and } \\
\text { public land survey system base layer }\end{array}$ \\
\hline $\begin{array}{l}\text { sleetmute_emanomalies_sim_magtf_contours_ } \\
\text { detailed_topo_map_1 of6.pdf }\end{array}$ & $\begin{array}{l}\text { EM anomaly map with simulated magnetic total field grid contours and } \\
\text { topographic base map }\end{array}$ \\
\hline $\begin{array}{l}\text { sleetmute_emanomalies_sim_magtf_contours_ } \\
\text { detailed_topo_map_2of6.pdf }\end{array}$ & $\begin{array}{l}\text { EM anomaly map with simulated magnetic total field grid contours and } \\
\text { topographic base map }\end{array}$ \\
\hline $\begin{array}{l}\text { sleetmute_emanomalies_sim_magtf_contours_ } \\
\text { detailed_topo_map_3of6.pdf }\end{array}$ & $\begin{array}{l}\text { EM anomaly map with simulated magnetic total field grid contours and } \\
\text { topographic base map }\end{array}$ \\
\hline $\begin{array}{l}\text { sleetmute_emanomalies_sim_magtf_contours_ } \\
\text { detailed_topo_map_4of6.pdf }\end{array}$ & $\begin{array}{l}\text { EM anomaly map with simulated magnetic total field grid contours and } \\
\text { topographic base map }\end{array}$ \\
\hline $\begin{array}{l}\text { sleetmute_emanomalies_sim_magtf_contours_ } \\
\text { detailed_topo_map_5of6.pdf }\end{array}$ & $\begin{array}{l}\text { EM anomaly map with simulated magnetic total field grid contours and } \\
\text { topographic base map }\end{array}$ \\
\hline $\begin{array}{l}\text { sleetmute_emanomalies_sim_magtf_contours_ } \\
\text { detailed_topo_map_6of6.pdf }\end{array}$ & $\begin{array}{l}\text { EM anomaly map with simulated magnetic total field grid contours and } \\
\text { topographic base map }\end{array}$ \\
\hline sleetmute_res7200hz_topo_map_1of2.pdf & 7,200 Hz apparent resistivity grid with topographic base map \\
\hline sleetmute_res7200hz_topo_map_2of2.pdf & 7,200 Hz apparent resistivity grid with topographic base map \\
\hline $\begin{array}{l}\text { sleetmute_res7200hz_contours_plss_map_1 of } 2 . \\
\text { pdf }\end{array}$ & $\begin{array}{l}7,200 \mathrm{~Hz} \text { apparent resistivity grid with contours and public land survey } \\
\text { system base layer }\end{array}$ \\
\hline $\begin{array}{l}\text { sleetmute_res7200hz_contours_plss_map_2of2. } \\
\text { pdf }\end{array}$ & $\begin{array}{l}7,200 \mathrm{~Hz} \text { apparent resistivity grid with contours and public land survey } \\
\text { system base layer }\end{array}$ \\
\hline $\begin{array}{l}\text { sleetmute_res7200hz_bw_contours_plss_ } \\
\text { map_1of2.pdf }\end{array}$ & $\begin{array}{l}\text { black and white } 7,200 \mathrm{~Hz} \text { apparent resistivity grid with contours and public } \\
\text { land survey system base layer }\end{array}$ \\
\hline $\begin{array}{l}\text { sleetmute_res7200hz_bw_contours_plss_ } \\
\text { map_2of2.pdf }\end{array}$ & $\begin{array}{l}\text { black and white } 7,200 \mathrm{~Hz} \text { apparent resistivity grid with contours and public } \\
\text { land survey system base layer }\end{array}$ \\
\hline
\end{tabular}


Table 1, continued. Copies of the following maps are included at the end of this booklet. The low-resolution, page-size maps included in this booklet are intended to be used as a search tool and are not the final product. Large-scale, full-resolution versions of each map are available to download on this publication's citation page: http://doi.org/10.14509/30223.

\begin{tabular}{|l|l|}
\hline \multicolumn{1}{|c|}{ Map Title } & \multicolumn{1}{c|}{ Description } \\
\hline sleetmute_res900hz_topo_map_1of2.pdf & $900 \mathrm{~Hz}$ apparent resistivity grid with topographic base map \\
\hline sleetmute_res900hz_topo_map_2of2.pdf & $900 \mathrm{~Hz}$ apparent resistivity grid with topographic base map \\
\hline $\begin{array}{l}\text { sleetmute_res900hz_contours_plss_map_1 of2. } \\
\text { pdf }\end{array}$ & $\begin{array}{l}900 \mathrm{~Hz} \text { apparent resistivity grid with contours and public land survey system } \\
\text { base layer }\end{array}$ \\
\hline $\begin{array}{l}\text { sleetmute_res900hz_contours_plss_map_2of2. } \\
\text { pdf }\end{array}$ & $\begin{array}{l}900 \mathrm{~Hz} \text { apparent resistivity grid with contours and public land survey system } \\
\text { base layer }\end{array}$ \\
\hline $\begin{array}{l}\text { sleetmute_res900hz_bw_contours_plss_ } \\
\text { map_1of2.pdf }\end{array}$ & $\begin{array}{l}\text { black and white } 900 \mathrm{~Hz} \text { apparent resistivity grid with contours and public } \\
\text { land survey system base layer }\end{array}$ \\
\hline $\begin{array}{l}\text { sleetmute_res900hz_bw_contours_plss_ } \\
\text { map_2of2.pdf }\end{array}$ & $\begin{array}{l}\text { black and white } 900 \mathrm{~Hz} \text { apparent resistivity grid with contours and public } \\
\text { land survey system base layer }\end{array}$ \\
\hline sleetmute_flightpath_topo_map_1of2.pdf & flight lines with public land survey system base layer \\
\hline sleetmute_flightpath_topo_map_2of2.pdf & flight lines with public land survey system base layer \\
\hline sleetmute_interpretation_plss_map_10f2.pdf & $\begin{array}{l}\text { interpretation based on geophysical data with public land survey system } \\
\text { base layer }\end{array}$ \\
\hline sleetmute_interpretation_plss_map_2of2.pdf & $\begin{array}{l}\text { interpretation based on geophysical data with public land survey system } \\
\text { base layer }\end{array}$ \\
\hline
\end{tabular}









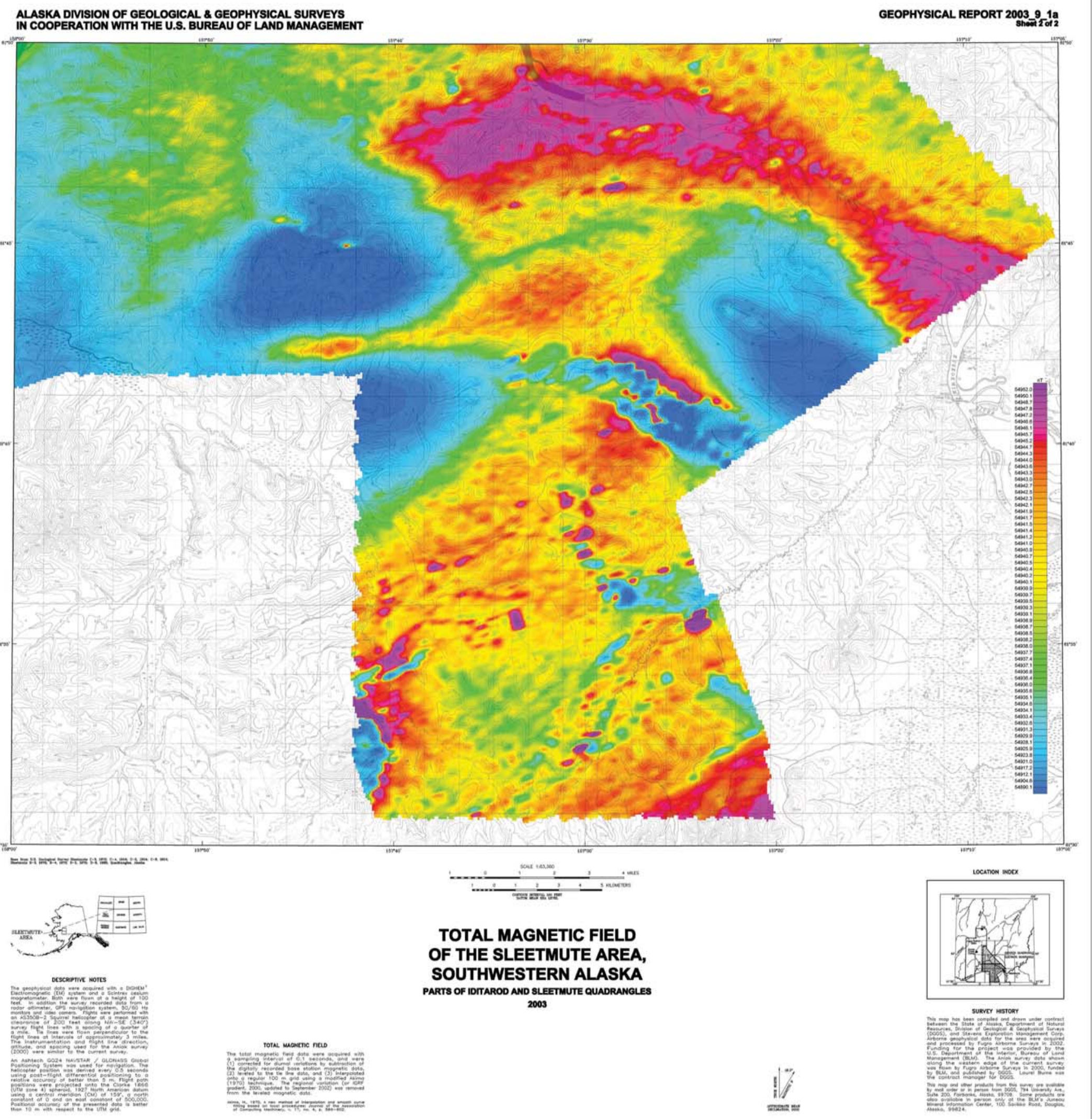




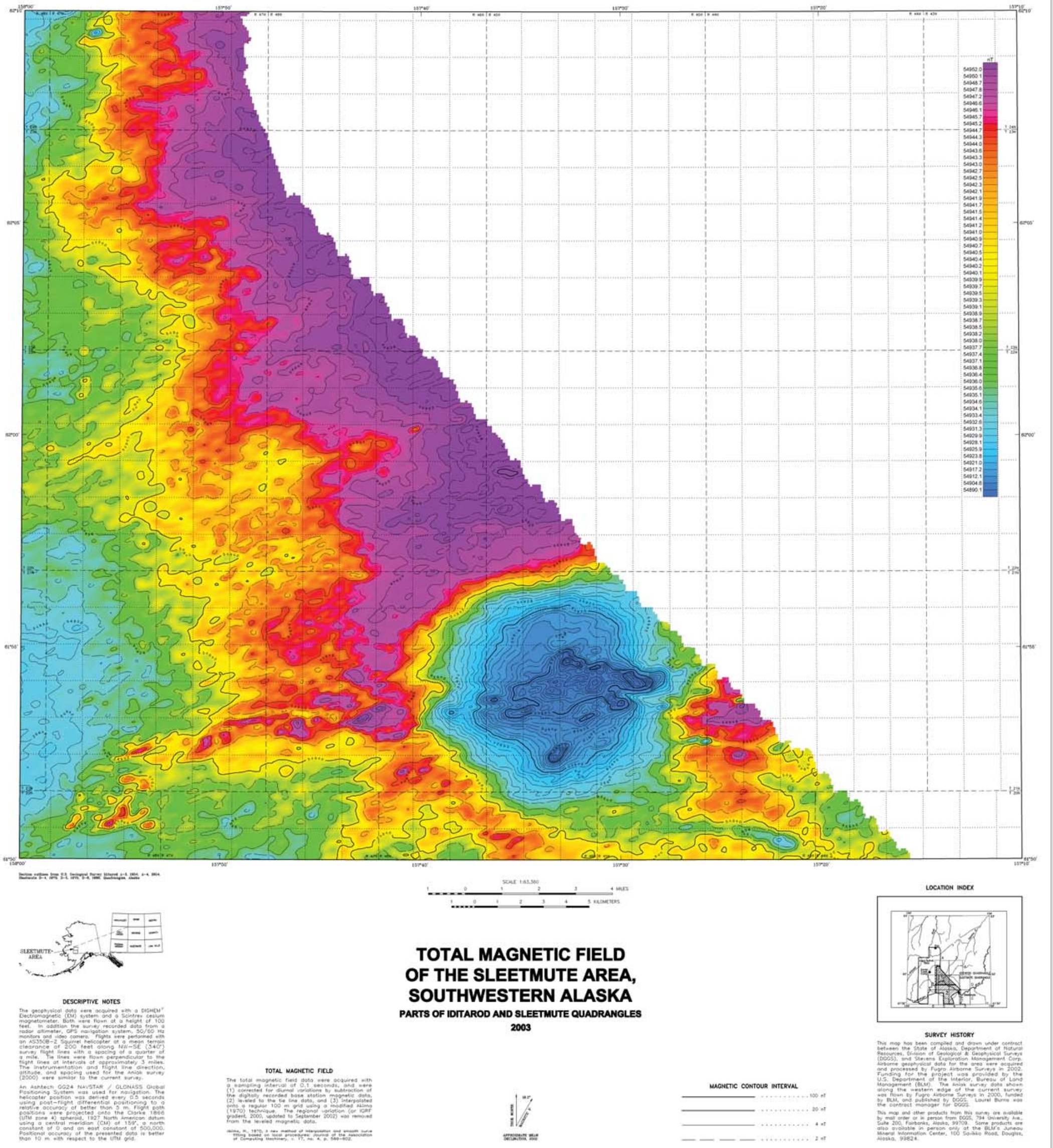









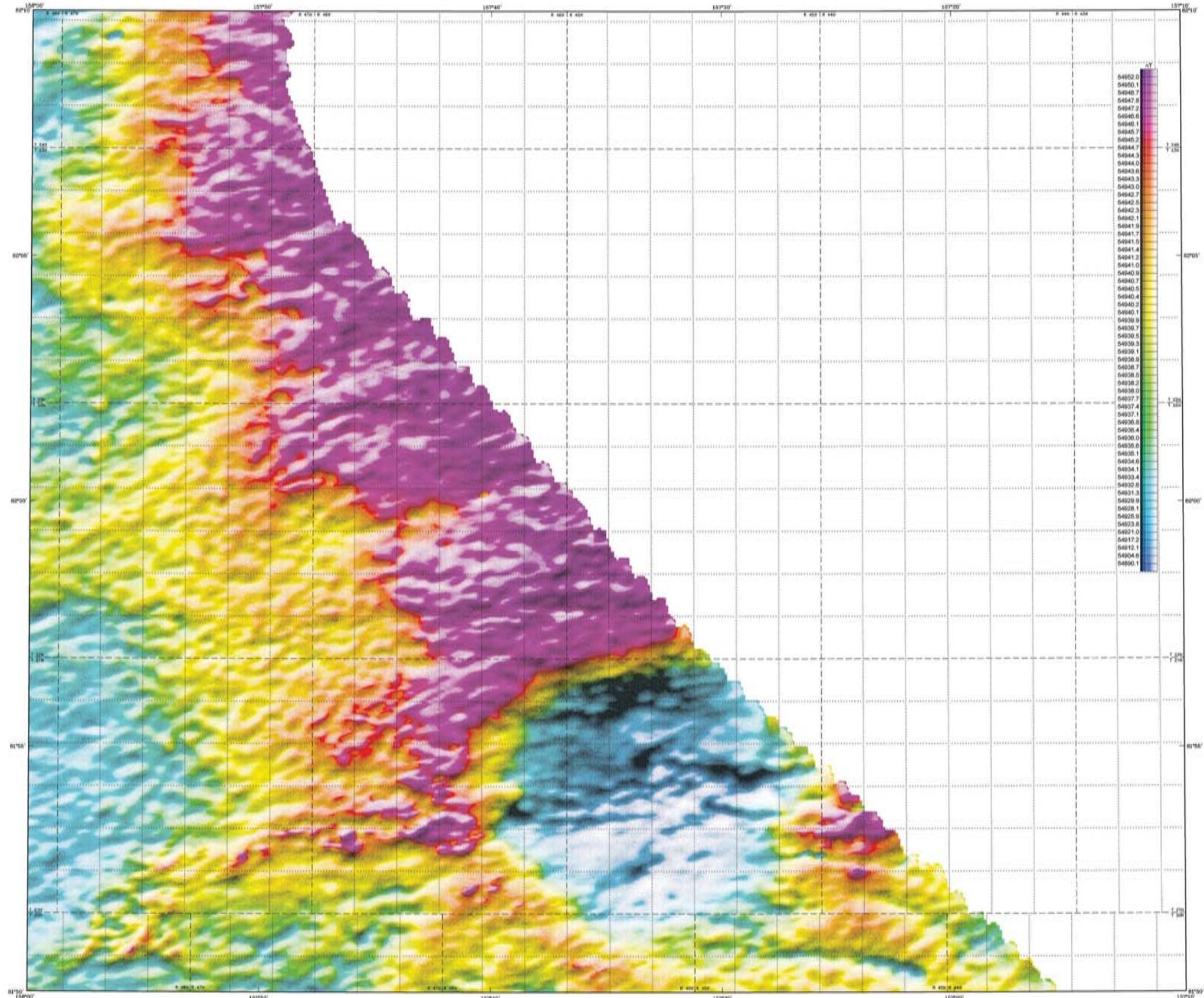

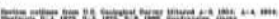
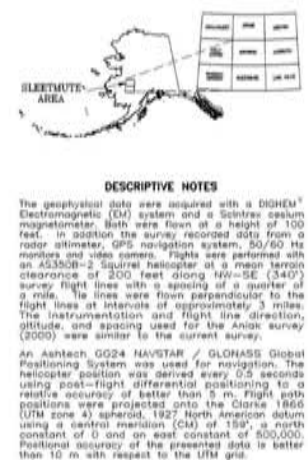

COLOR SHADOW TOTAL MAGNETIC FIELD OF THE SLEETMUTE AREA SOUTHWESTERN ALASKA PARTS OF IDITAROD AND SLEETMUTE QUADRANGLES

TOTAL MAQHETC FEL

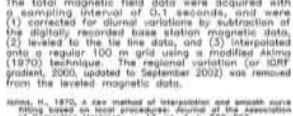
uth: 340 degree

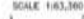
Inclination: 30 degrees

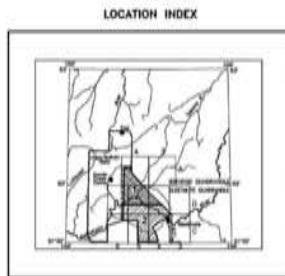

SURVCr Histor

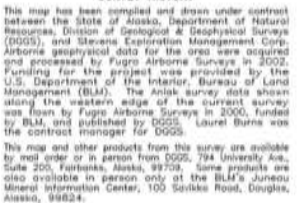




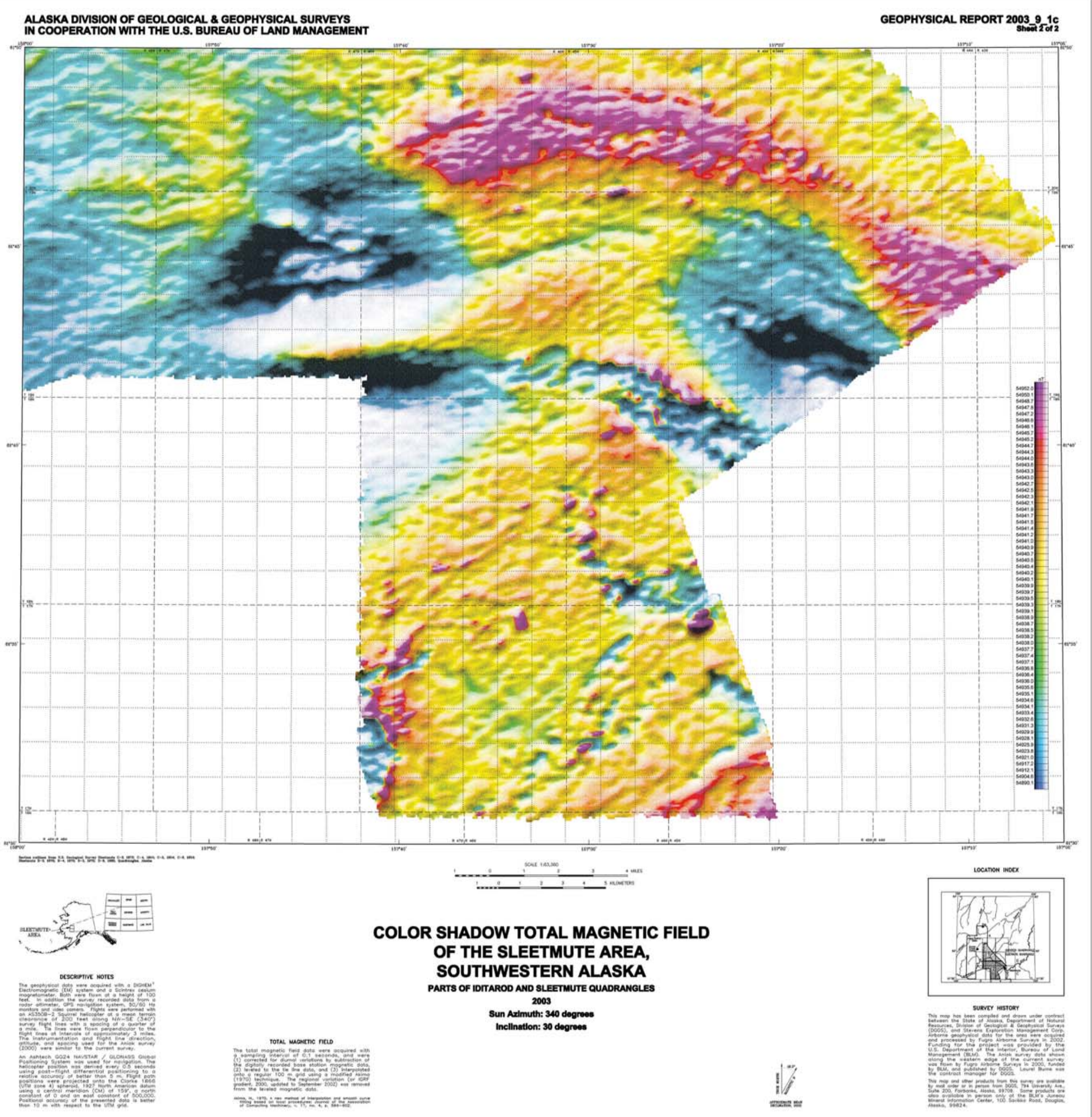




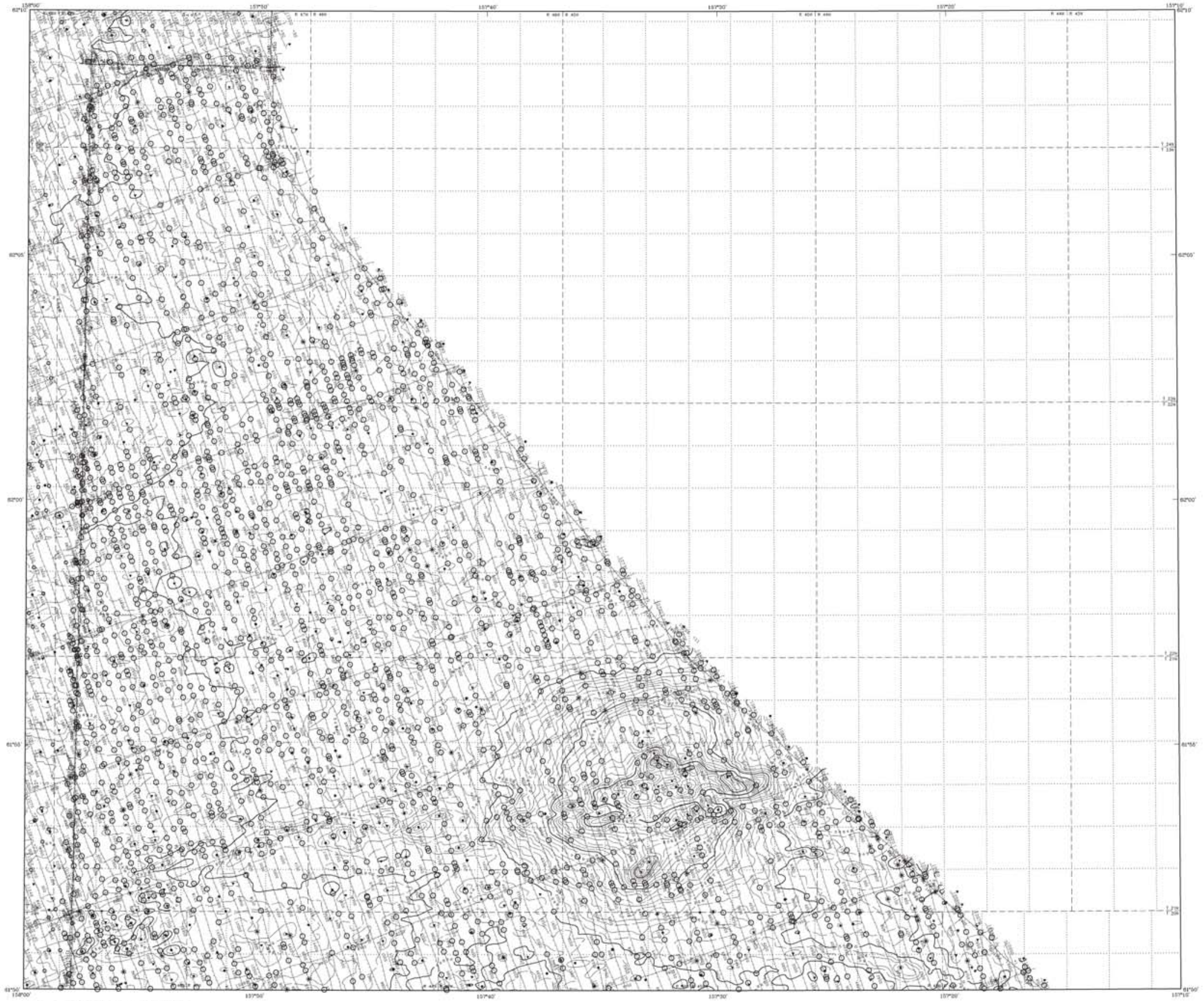

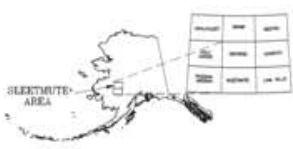

Deschiptive Norts

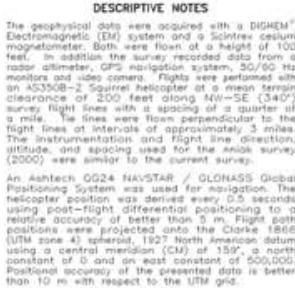

20

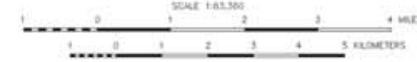

TOTAL MAGNETIC FIELD AND ELECTROMAGNETIC ANOMALIES OF THE SLEETMUTE AREA, SOUTHWESTERN ALASKA PARTS OF IDITAROD AND SLEETMUTE QUADRANGLES 2003
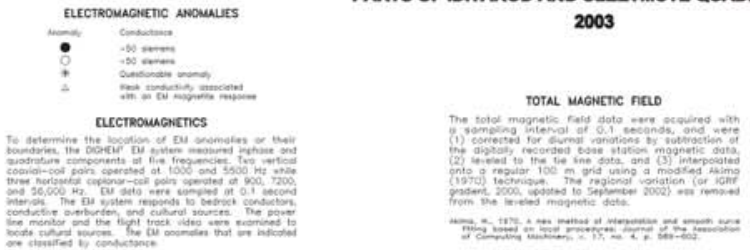

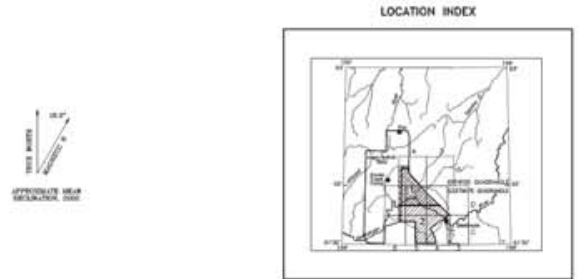

SURVEr Hestoor
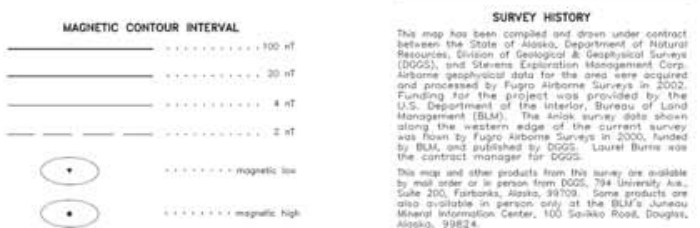

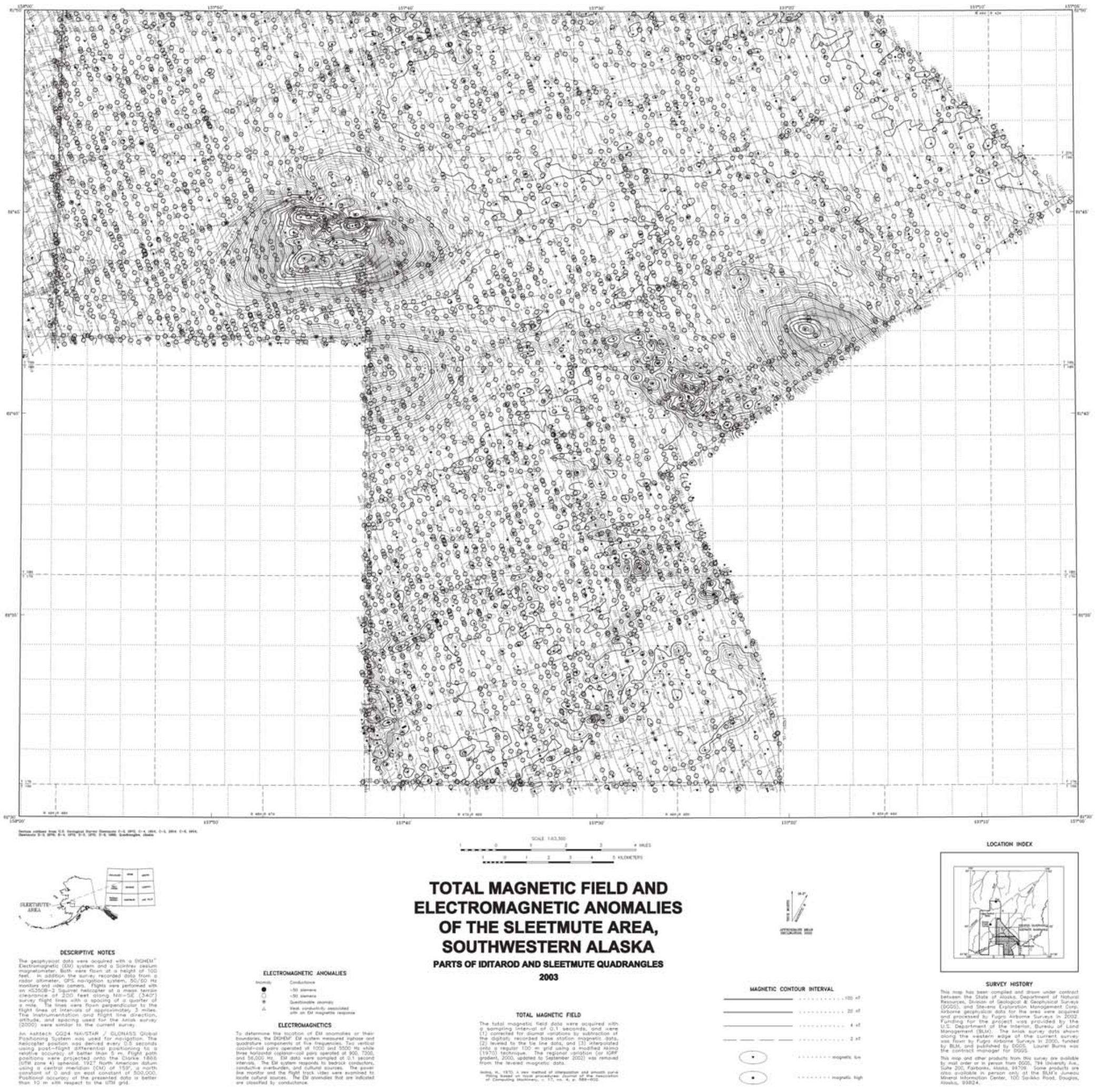

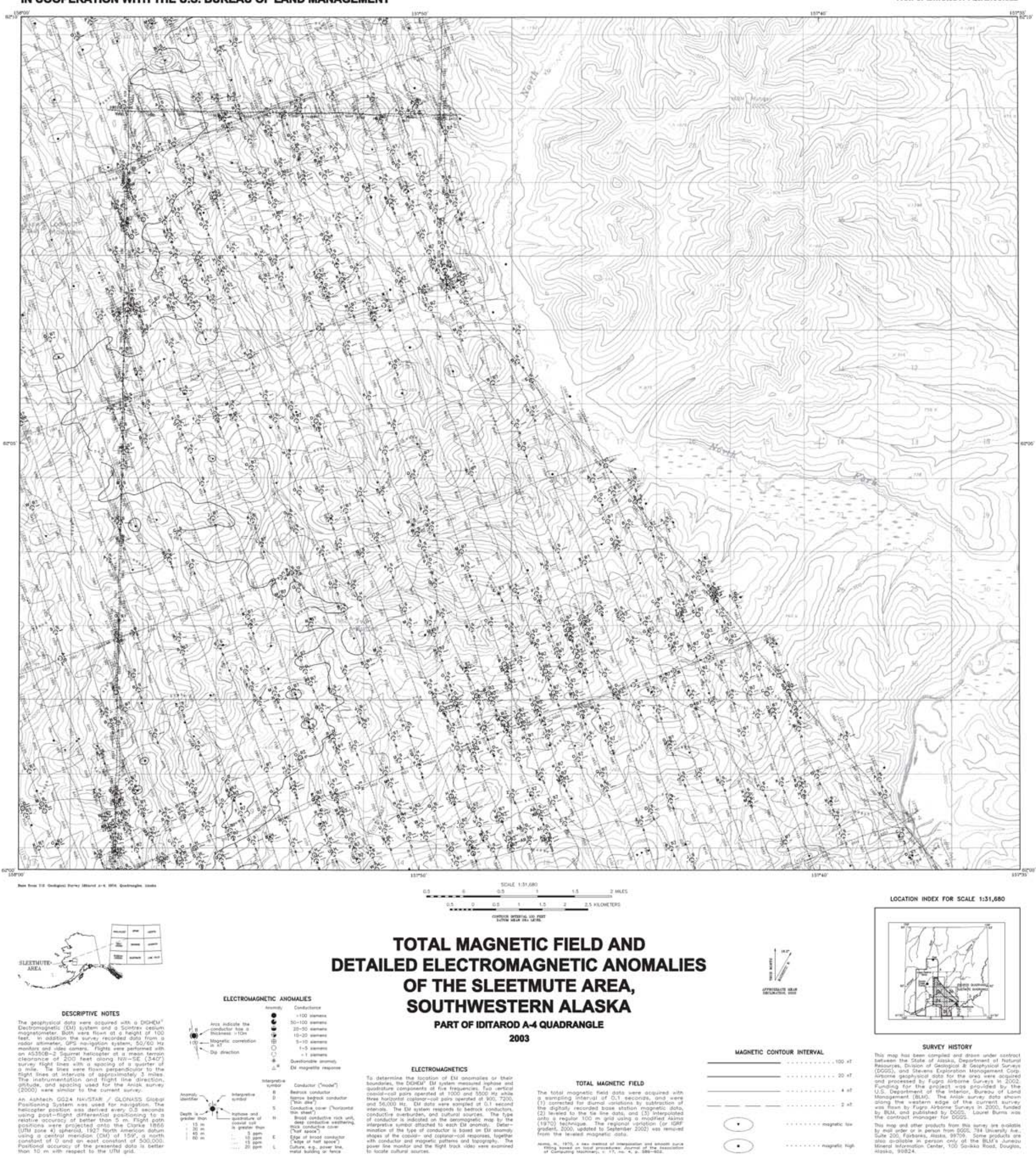

TOTAL MAGNETIC FIELD AND DETAILED ELECTROMAGNETIC ANOMALIES OF THE SLEETMUTE AREA, SOUTHWESTERN ALASKA

PART OF IDTTAROD A-4 QUADRANGLE

2003

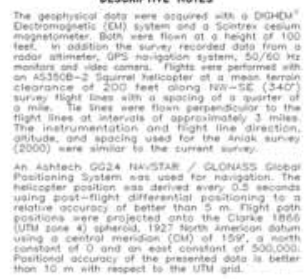

$$
=x-\frac{1}{1}=
$$
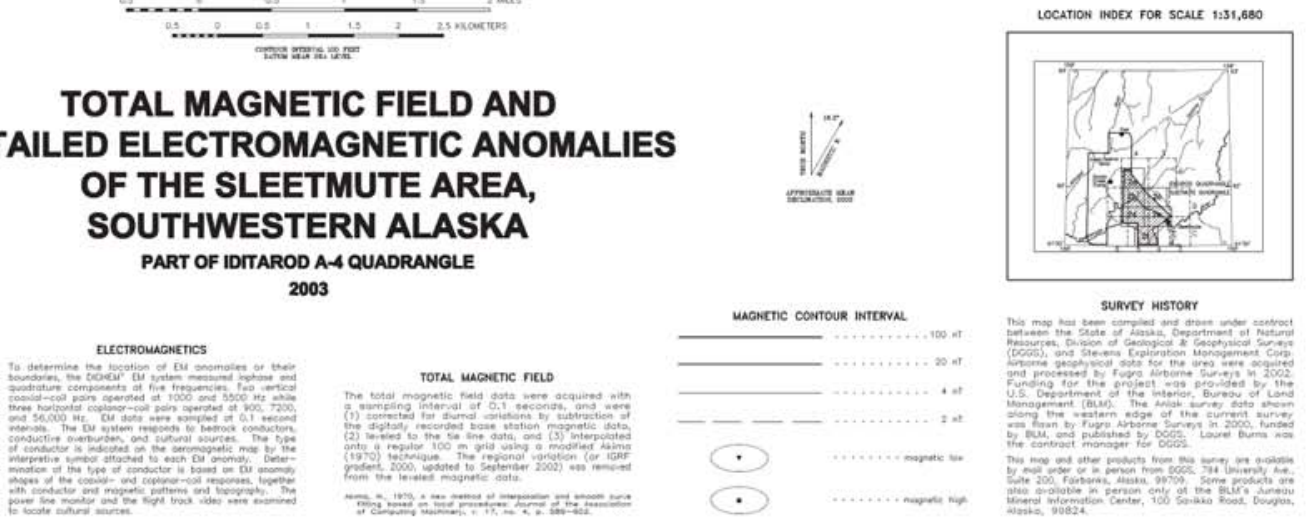

sunver Histoer

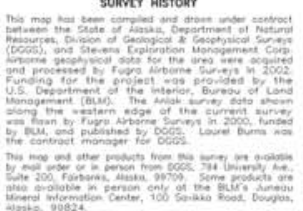




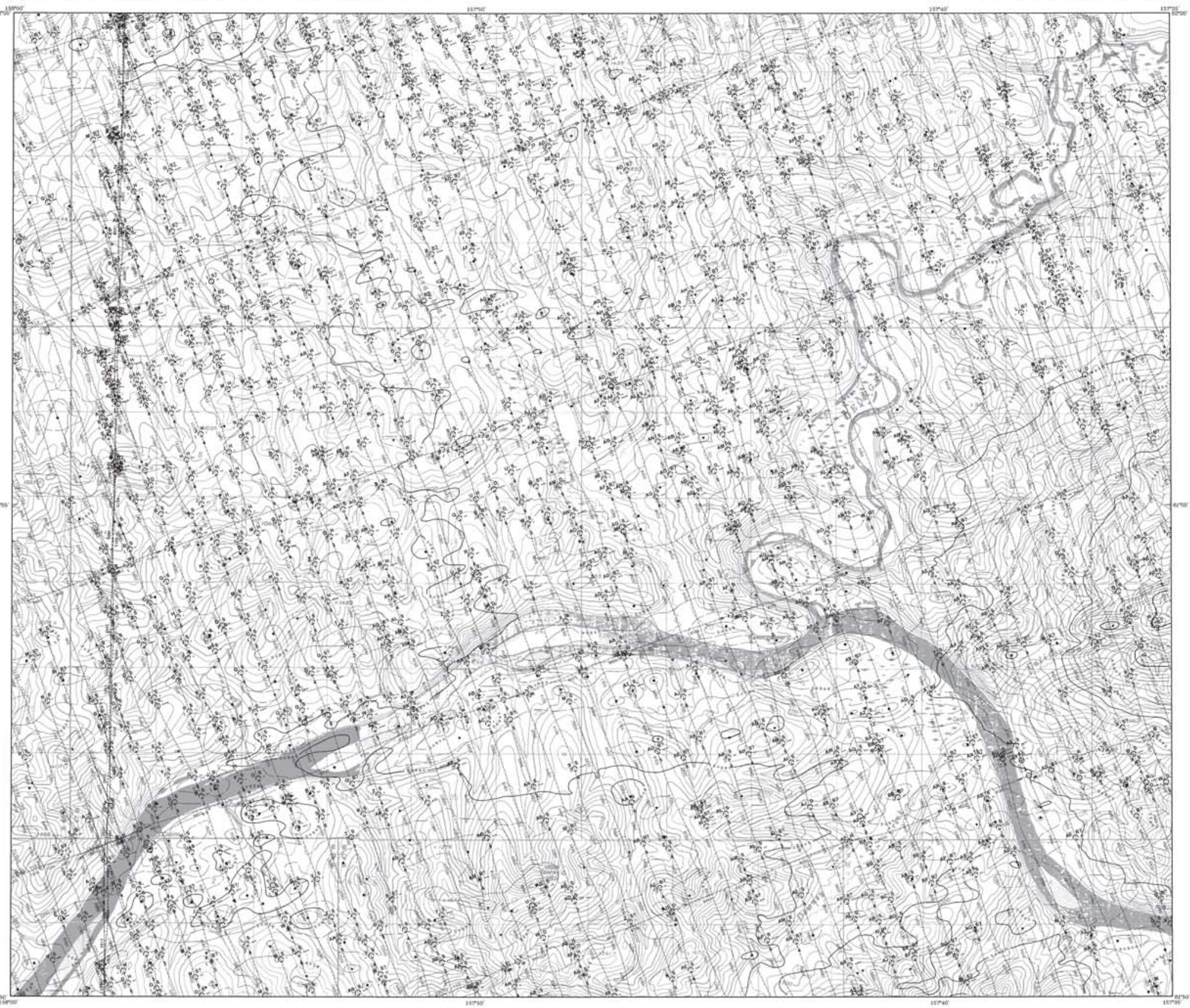

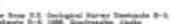
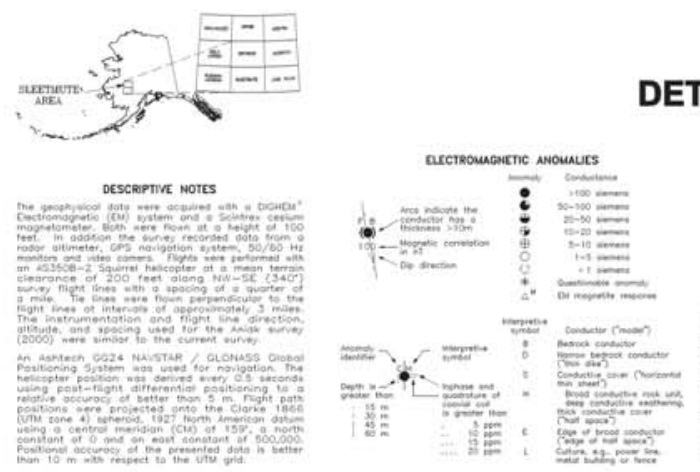

TOTAL MAGNETIC FIELD AND DETAILED ELECTROMAGNETIC ANOMALIES OF THE SLEETMUTE AREA, SOUTHWESTERN ALASKA
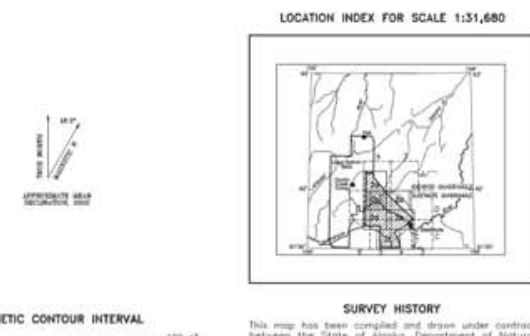
2003

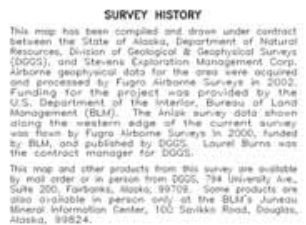






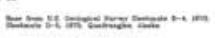
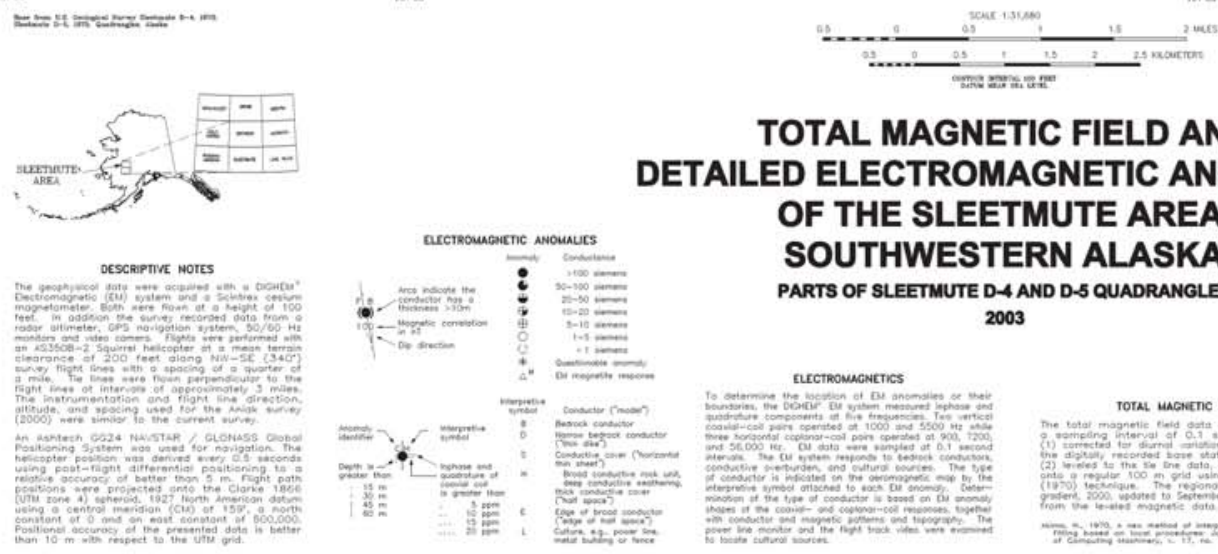

TOTAL MAGNETIC FIELD AND

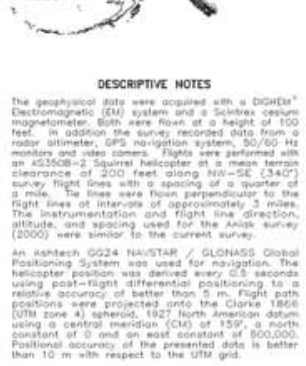

DETAILED ELECTROMAGNETIC ANOMALIES OF THE SLEETMUTE AREA, SOUTHWESTERN ALASKA

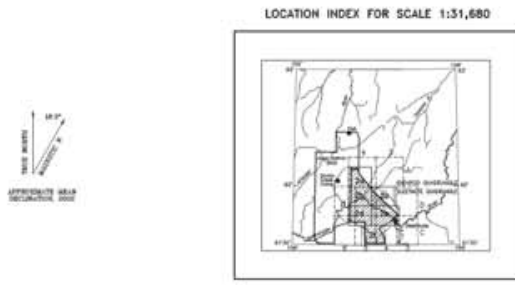

2003
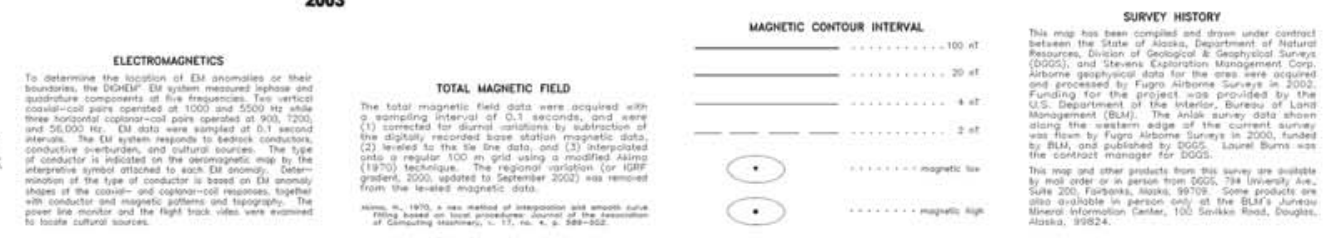


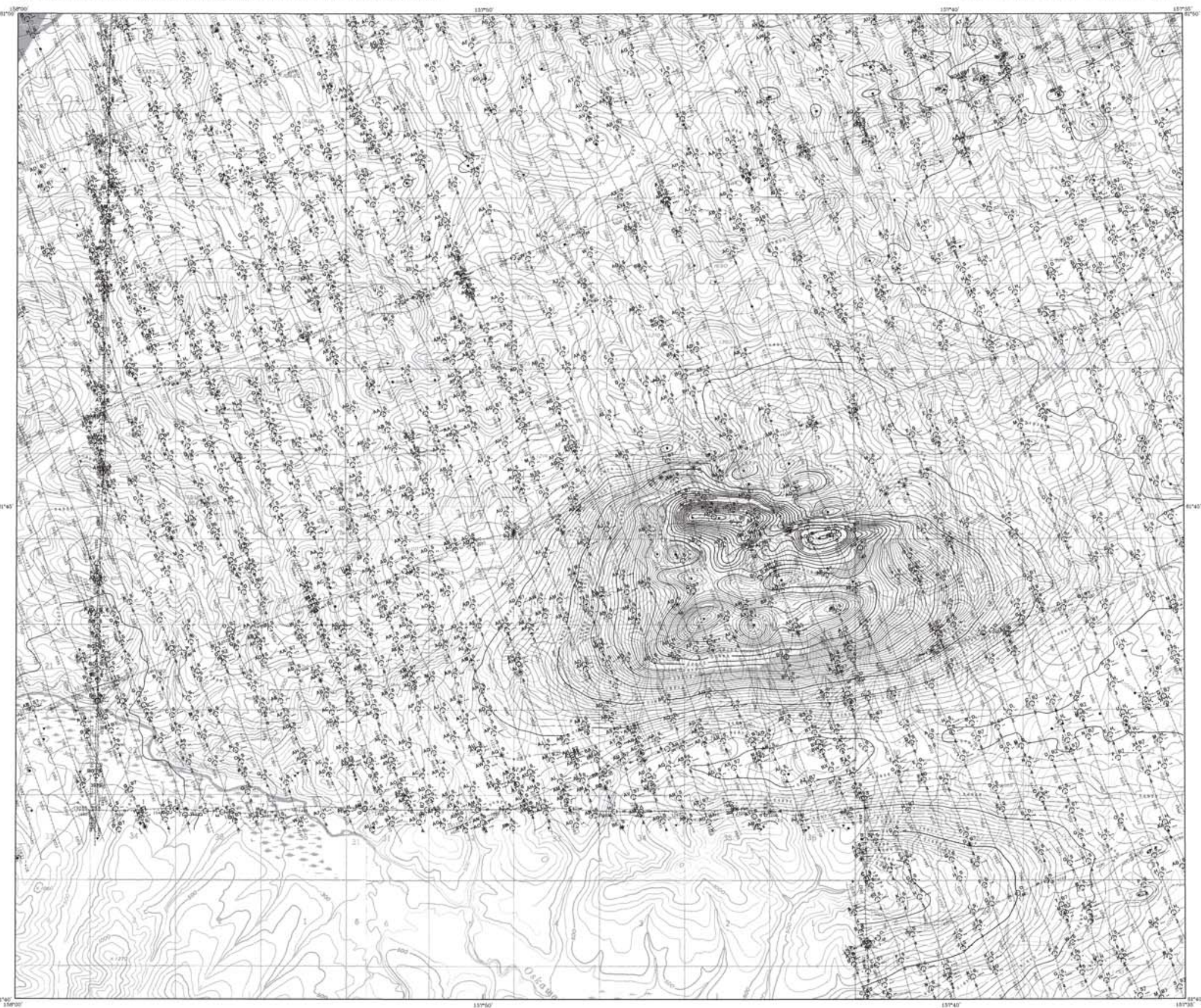

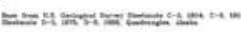
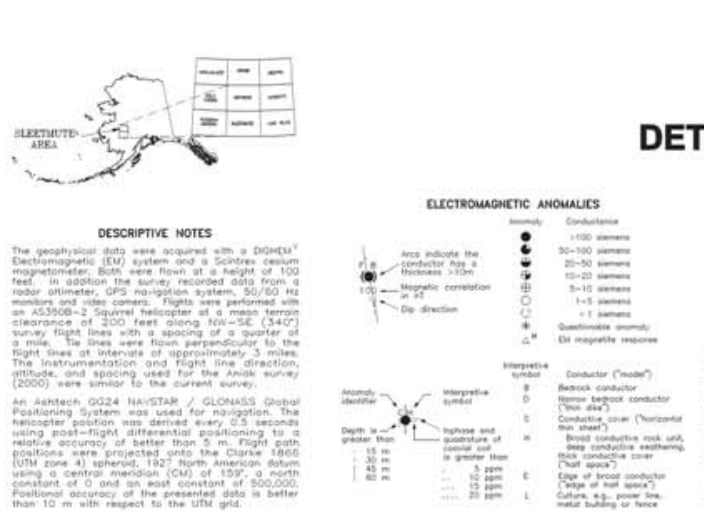

TOTAL MAGNETIC FIELD AND DETAILED ELECTROMAGNETIC ANOMALIES OF THE SLEETMUTE AREA, SOUTHWESTERN ALASKA

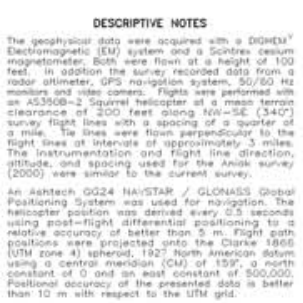
PARTS OF SLEETMUTE C-5, C-6, D-5 AND D-6 QUADRANGLES 2003
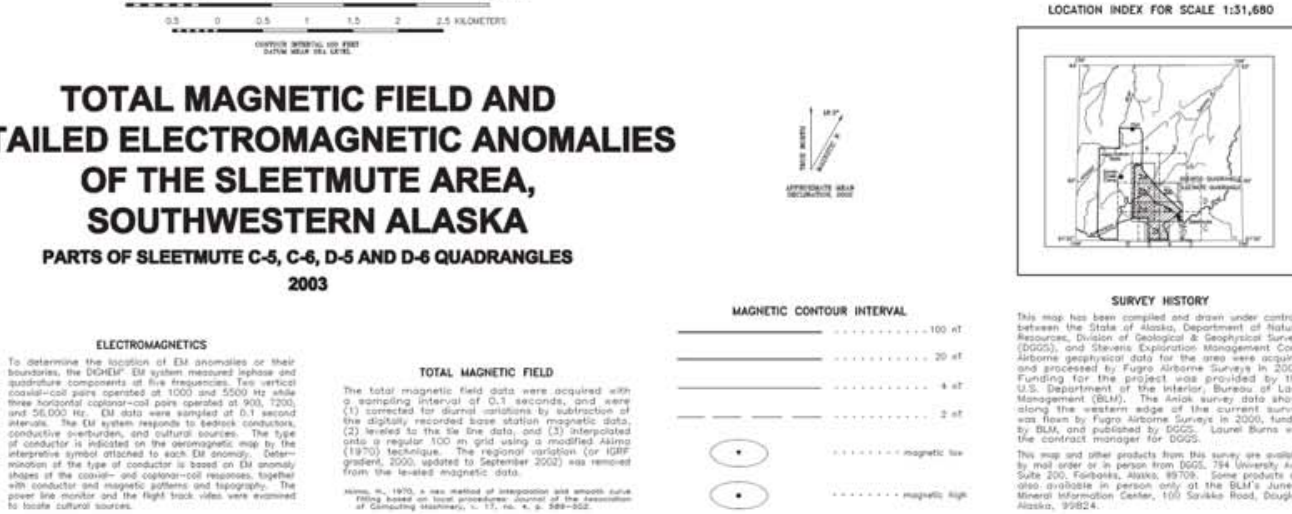

Sulaver iestoor 


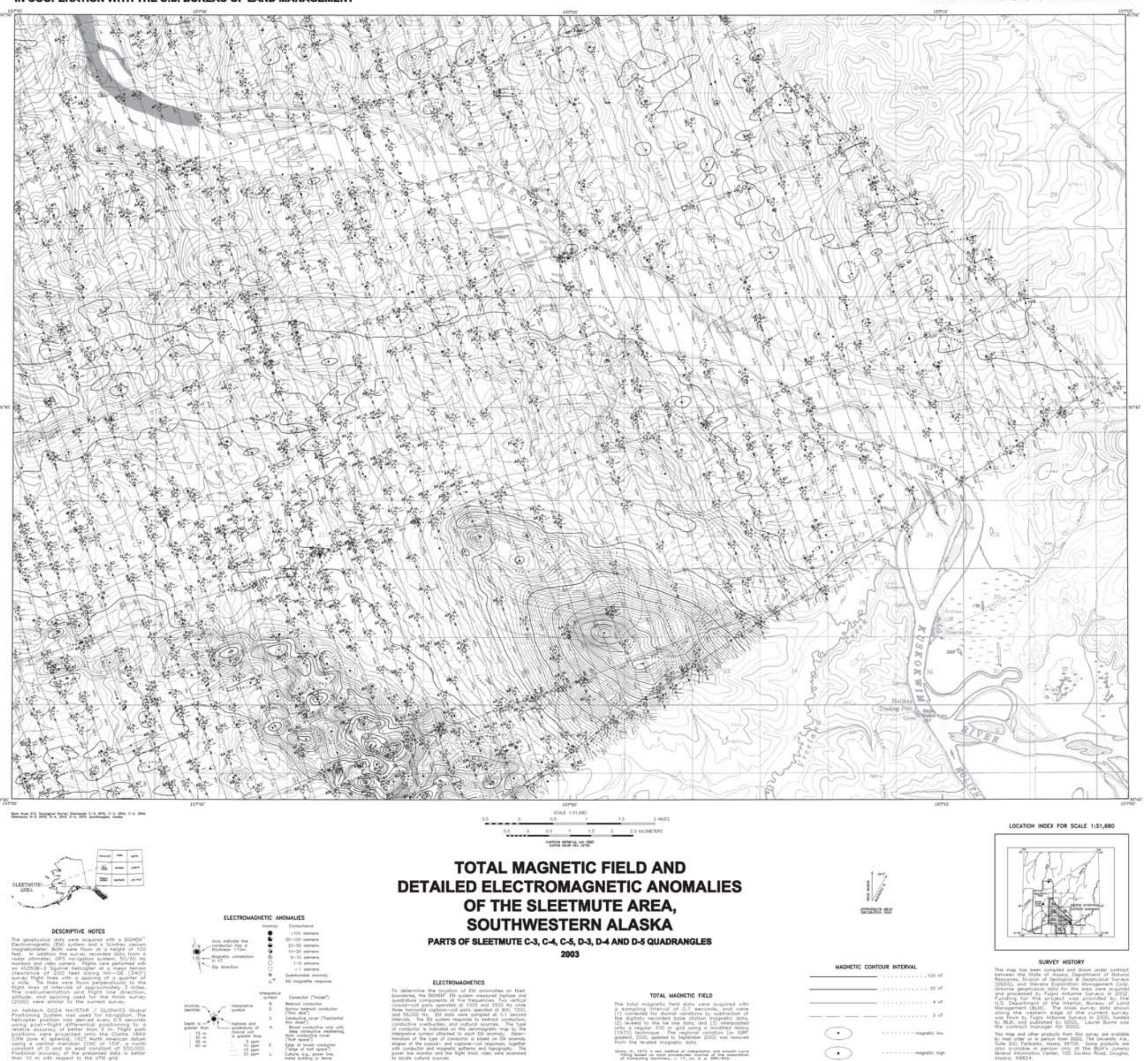




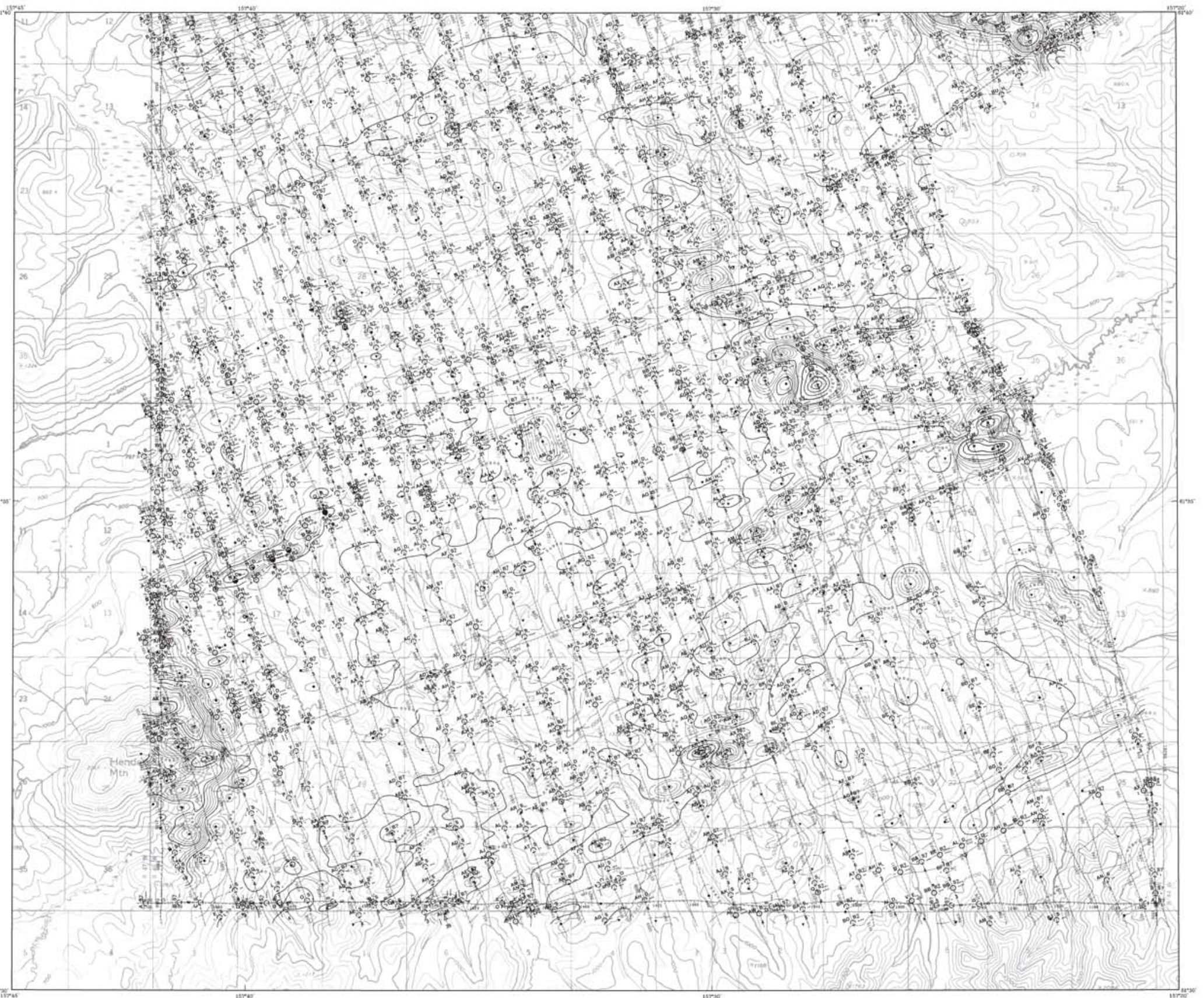

푸
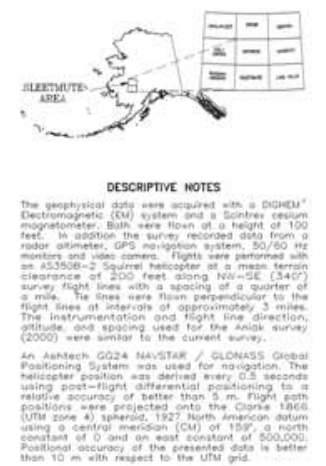

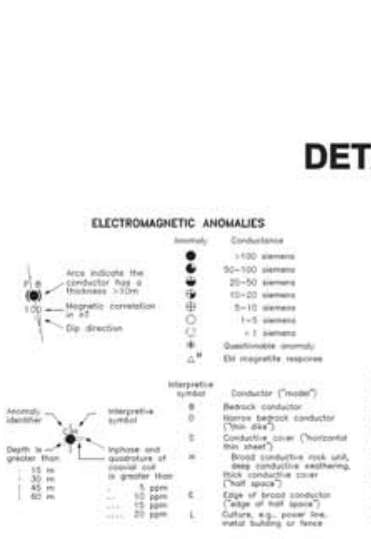

TOTAL MAGNETIC FIELD AND ED ELECTROMAGNETIC ANOMALIES OF THE SLEETMUTE AREA, SOUTHWESTERN ALASKA PARTS OF SLEETMUTE CA AND C- 5 QUADRANGLES 2003

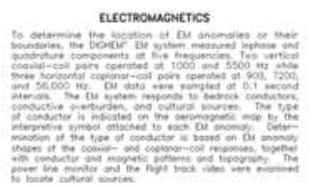

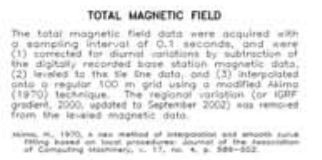

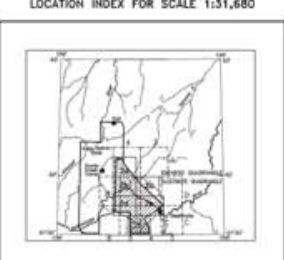

surver Hastokr 


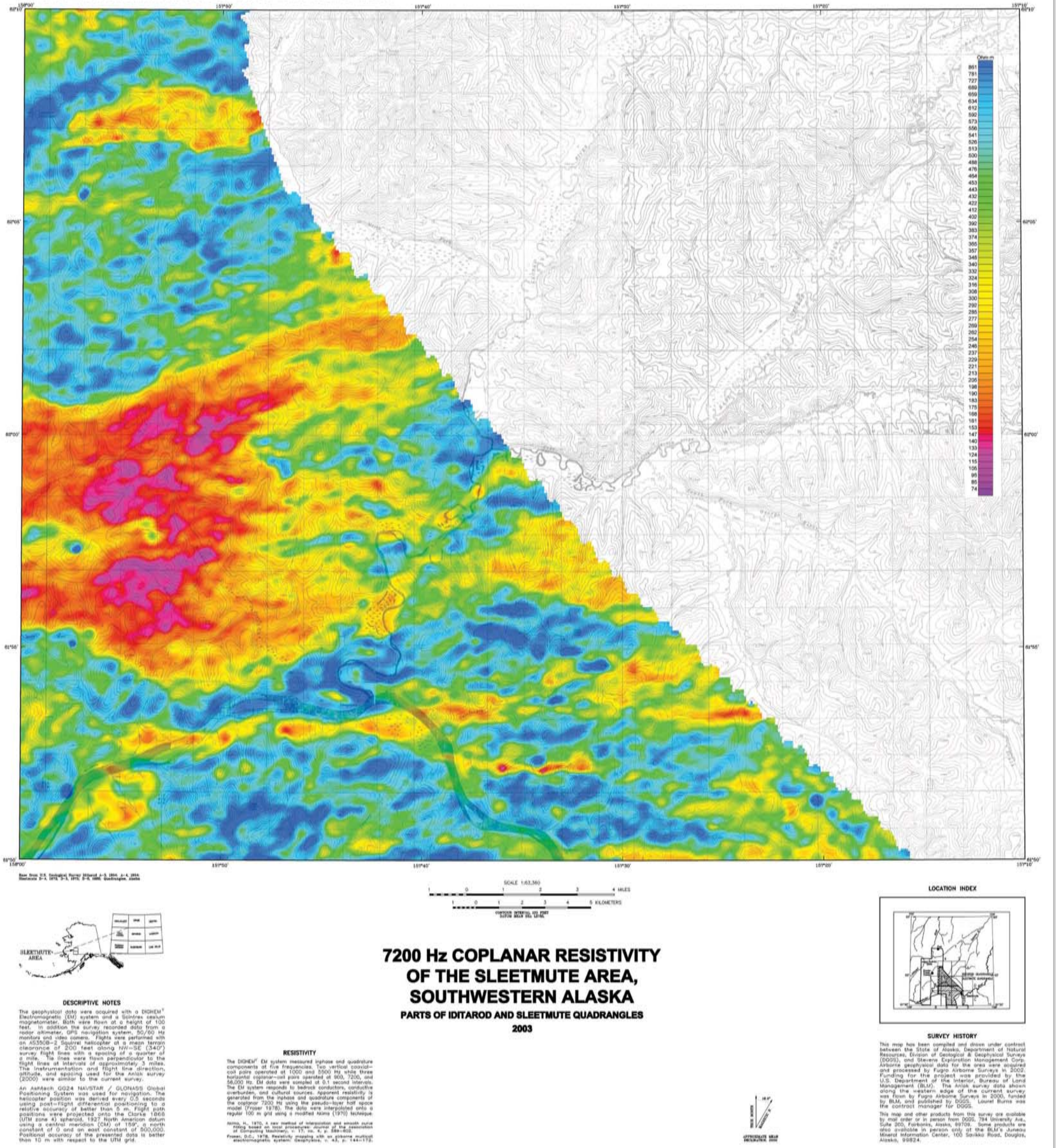




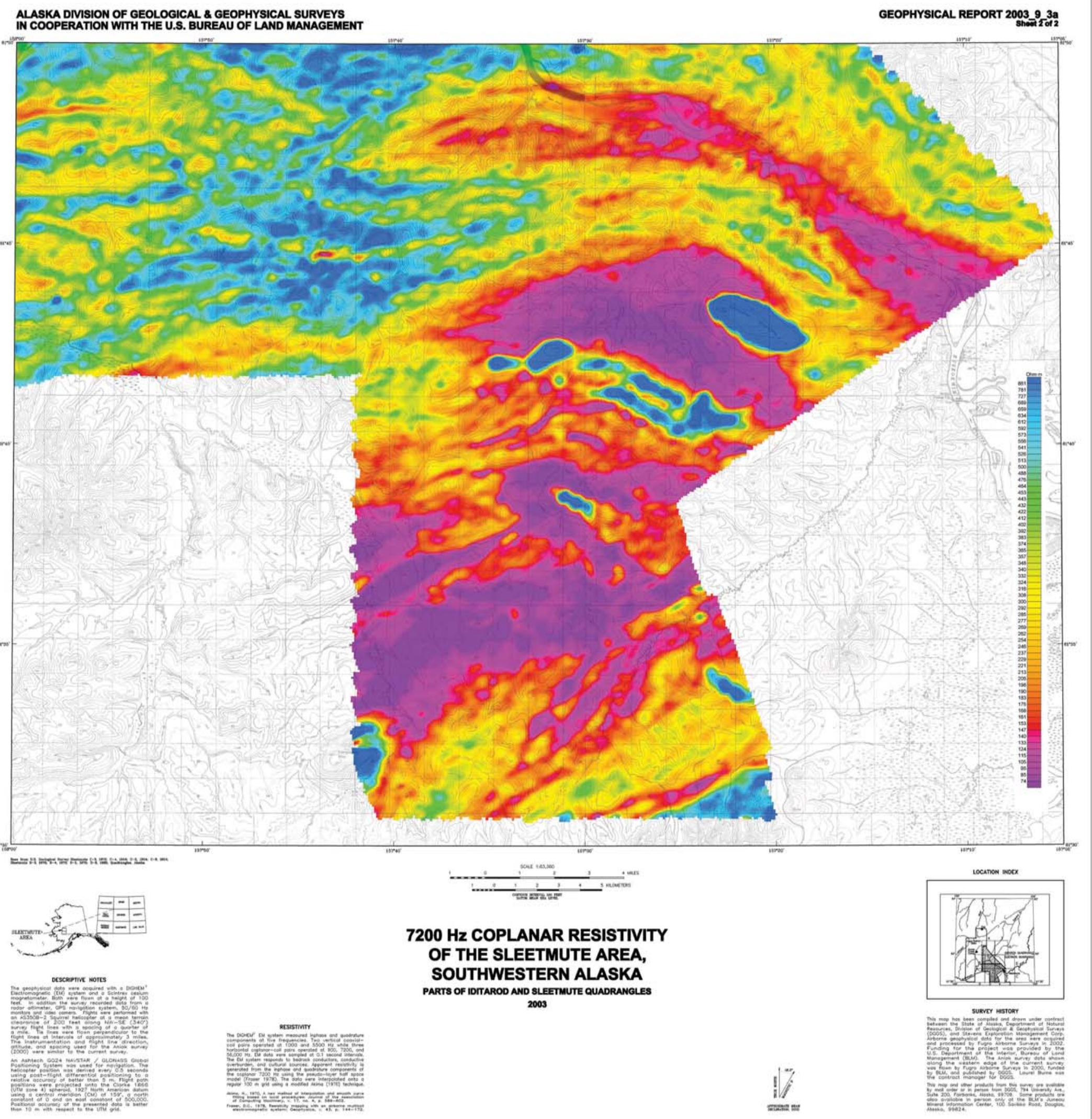




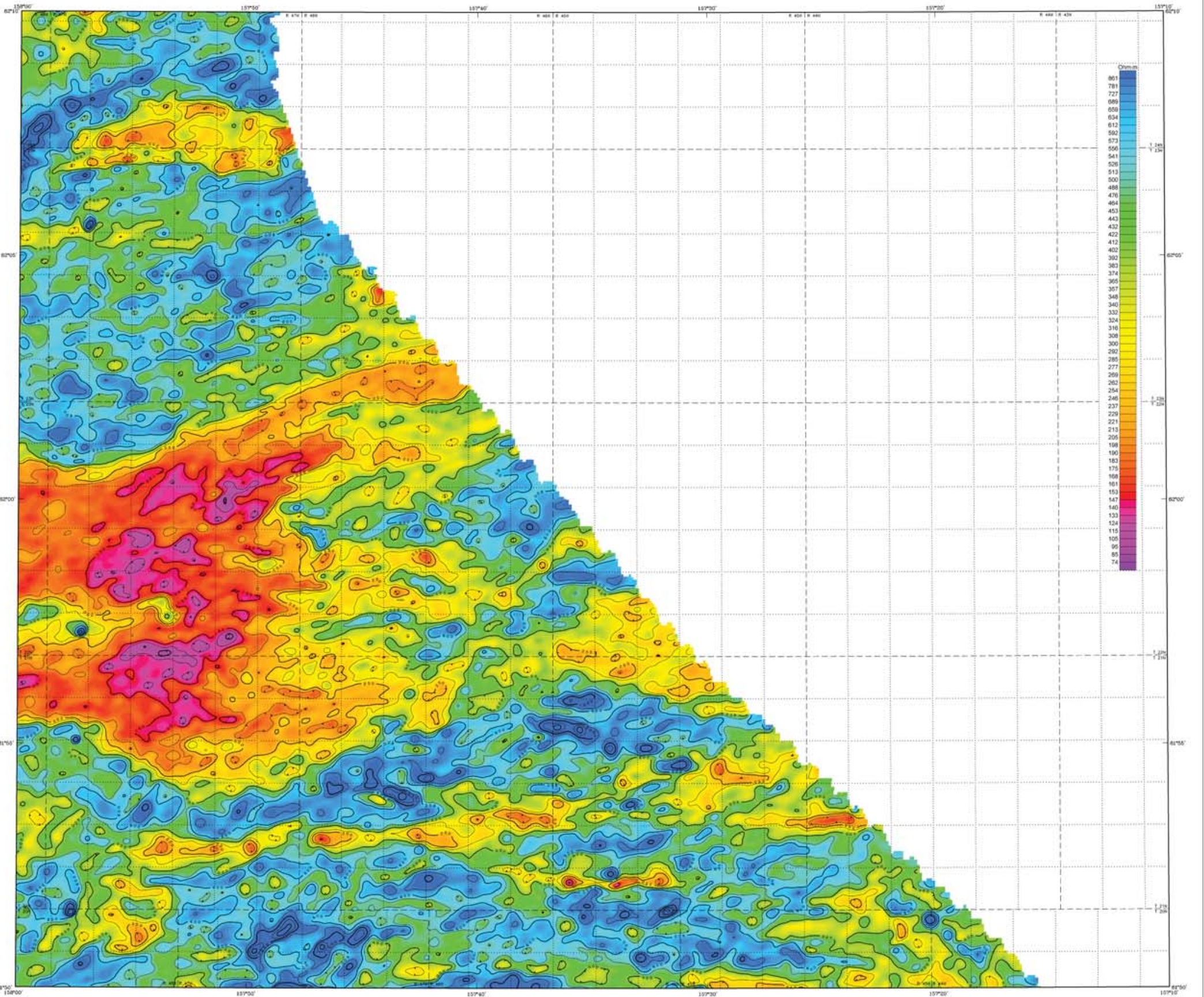

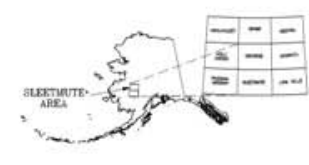

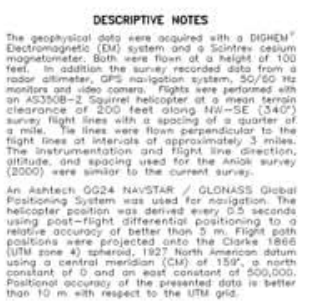

soner tassose

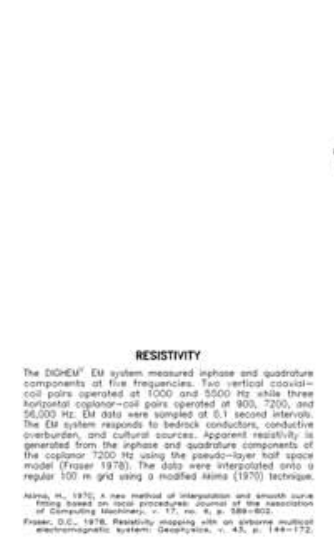

$7200 \mathrm{~Hz}$ COPLANAR RESISTIVITY OF THE SLEETMUTE AREA, SOUTHWESTERN ALASKA PARTS OF IDTTAROD AND SLEETMUTE QUADRANGLES 2003

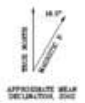

Resistweit cowtoues

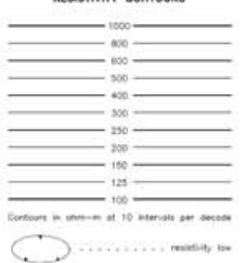

LOCATION MOCX

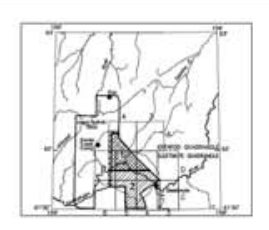

SURVEr Hestokr

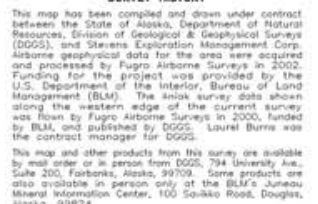




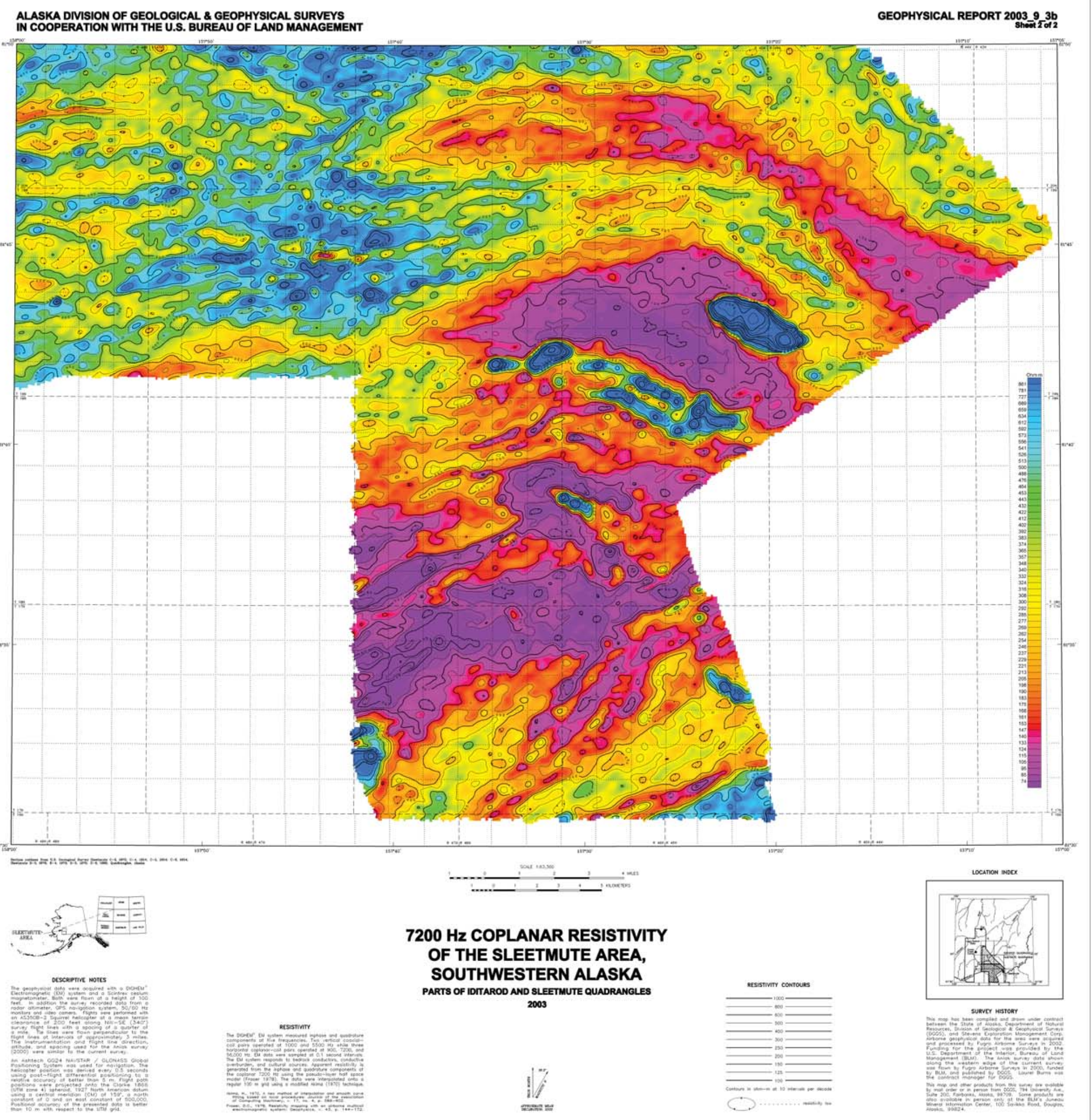




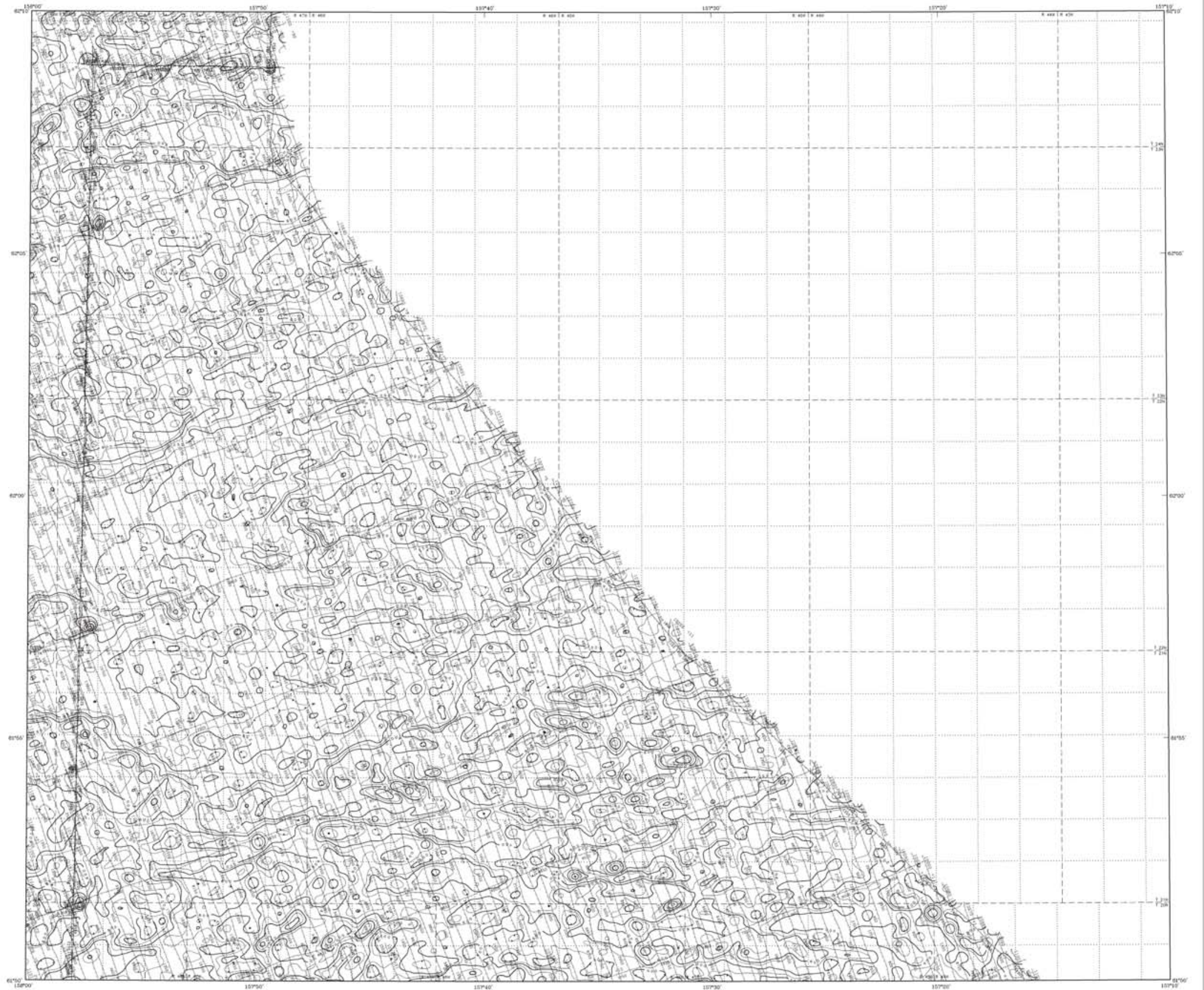

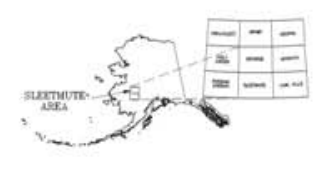

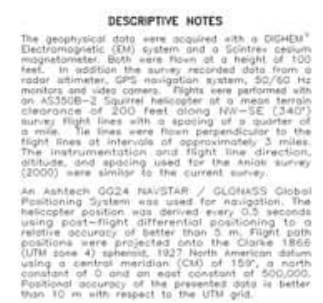

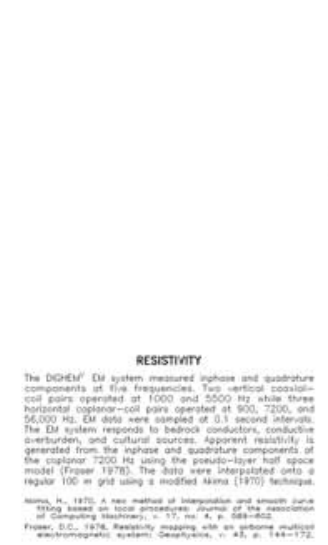

$7200 \mathrm{~Hz}$ COPLANAR RESISTIVITY OF THE SLEETMUTE AREA, SOUTHWESTERN ALASKA PARTS OF IDITAROD AND SLEETMUTE QUADRANGLES 2003

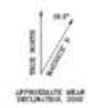

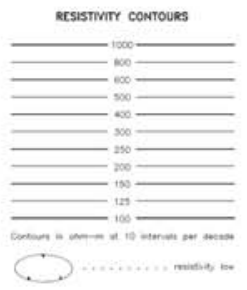

LOCATION BOEX

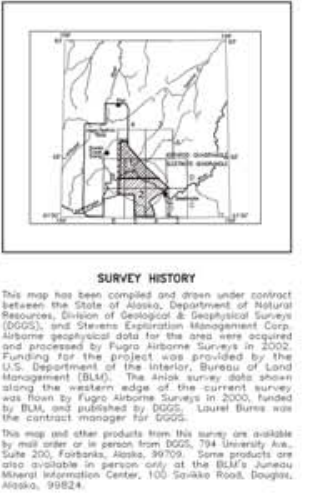



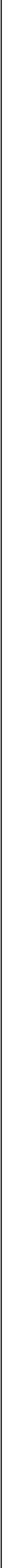

\section{$7200 \mathrm{~Hz}$ COPLANAR RESISTIVITY OF THE SLEETMUTE AREA, SOUTHWESTERN ALASKA} PARTS OF IDTTAROD AND SLEETMUTE QUADRANGLES
2003

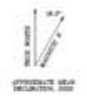

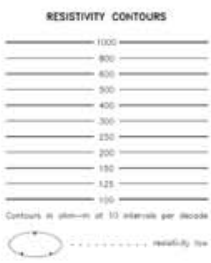

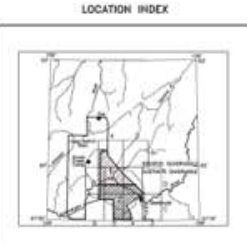

Suever Mestour

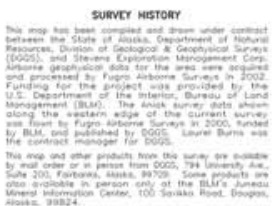




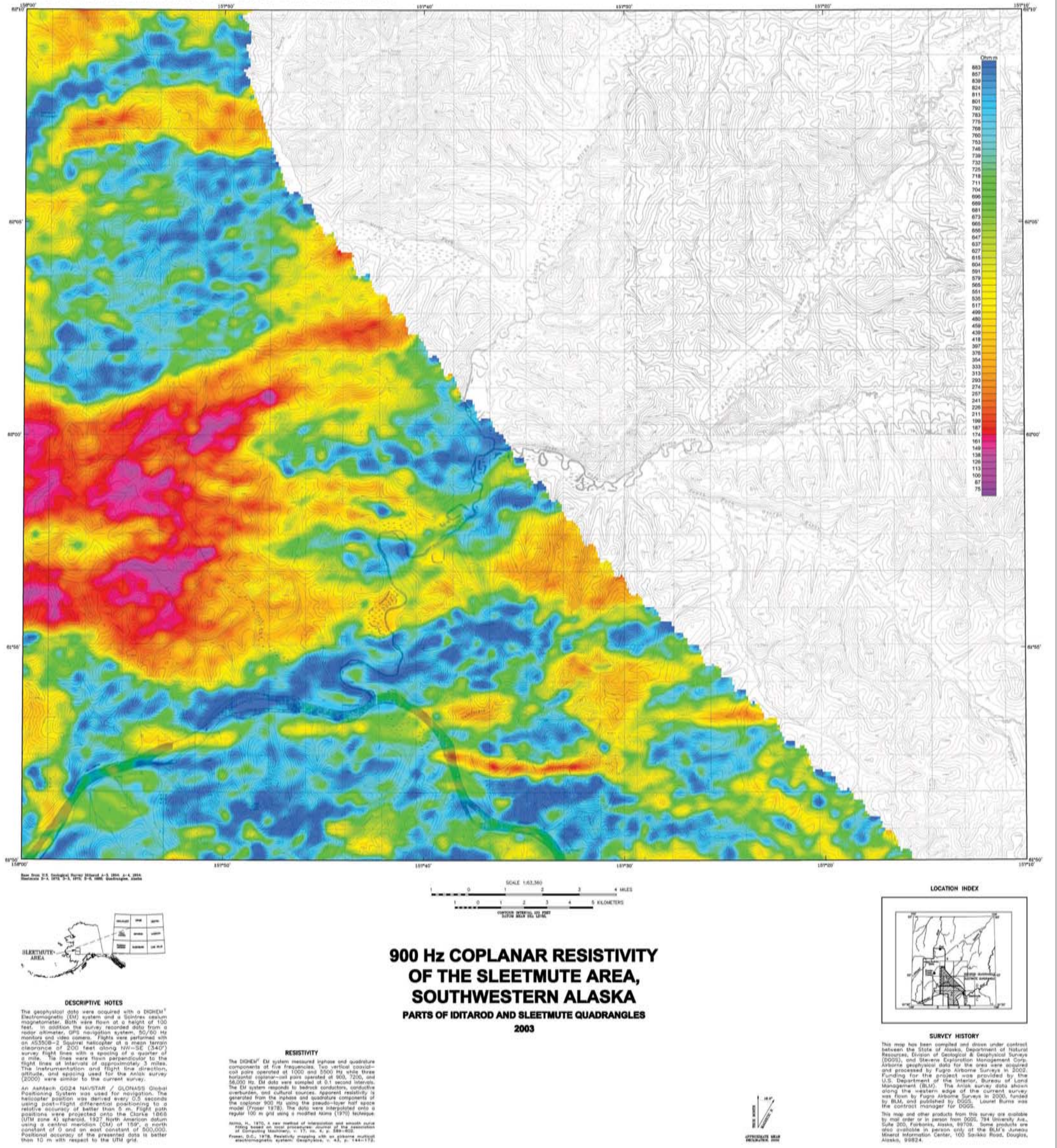




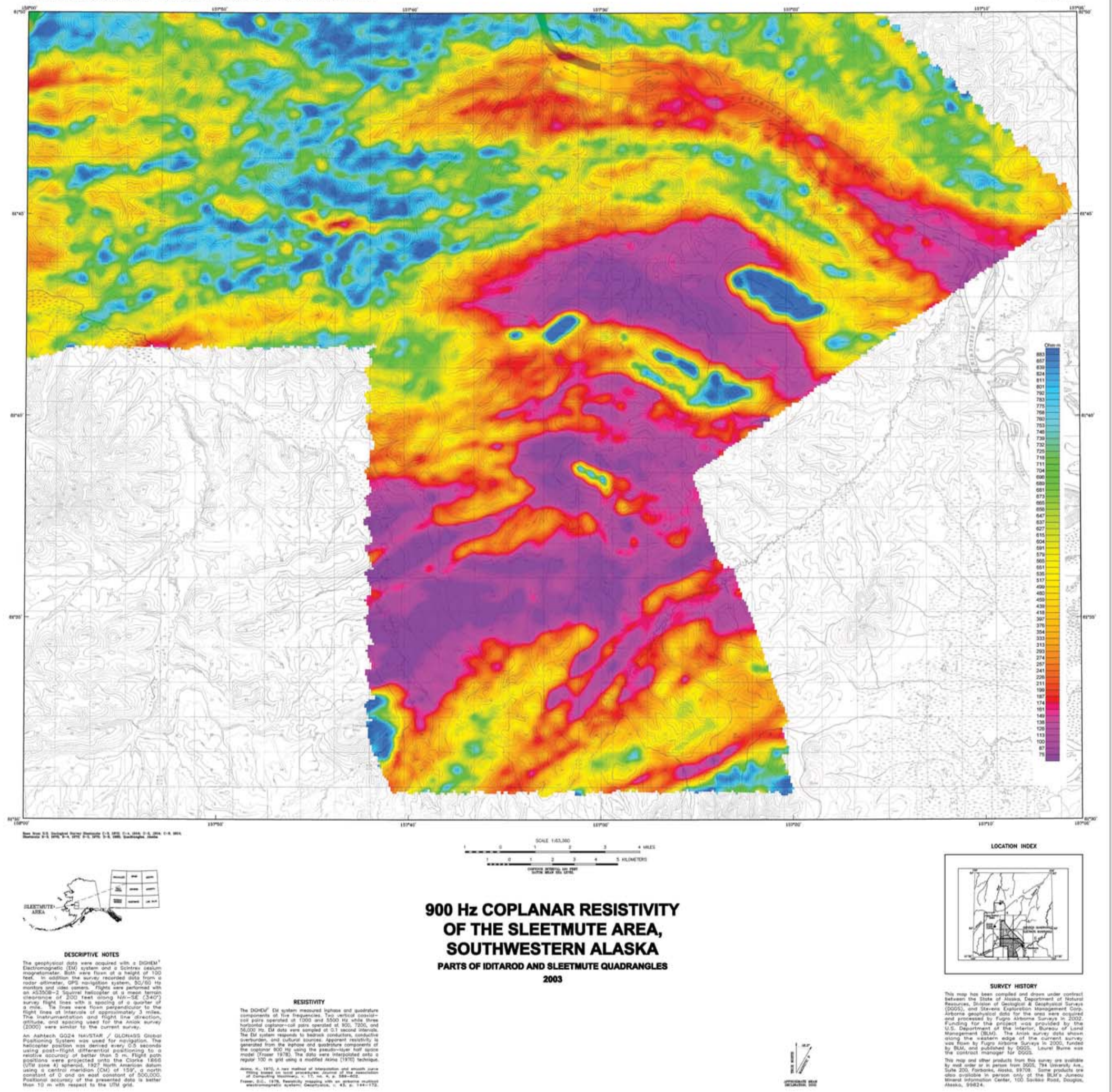




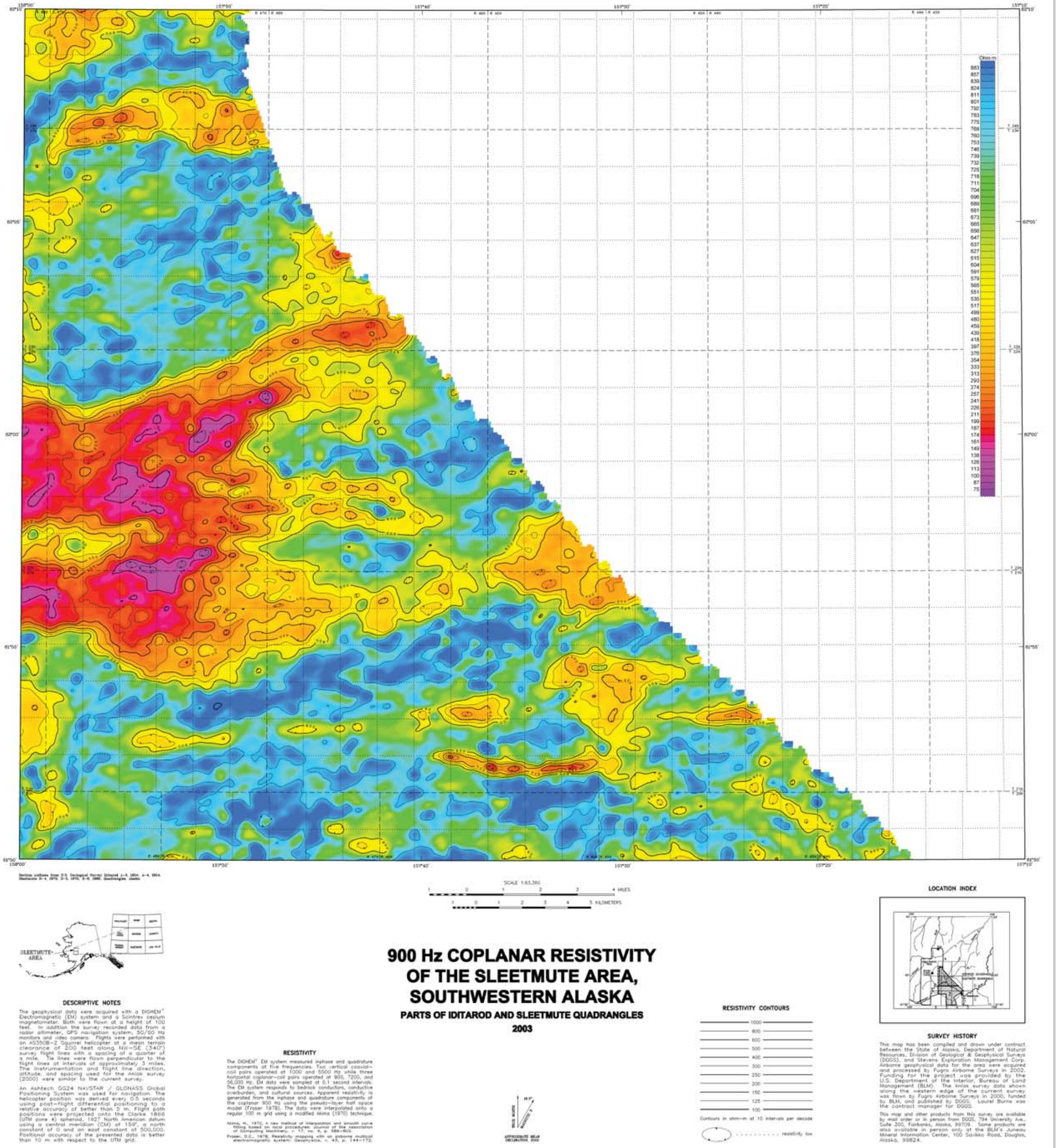




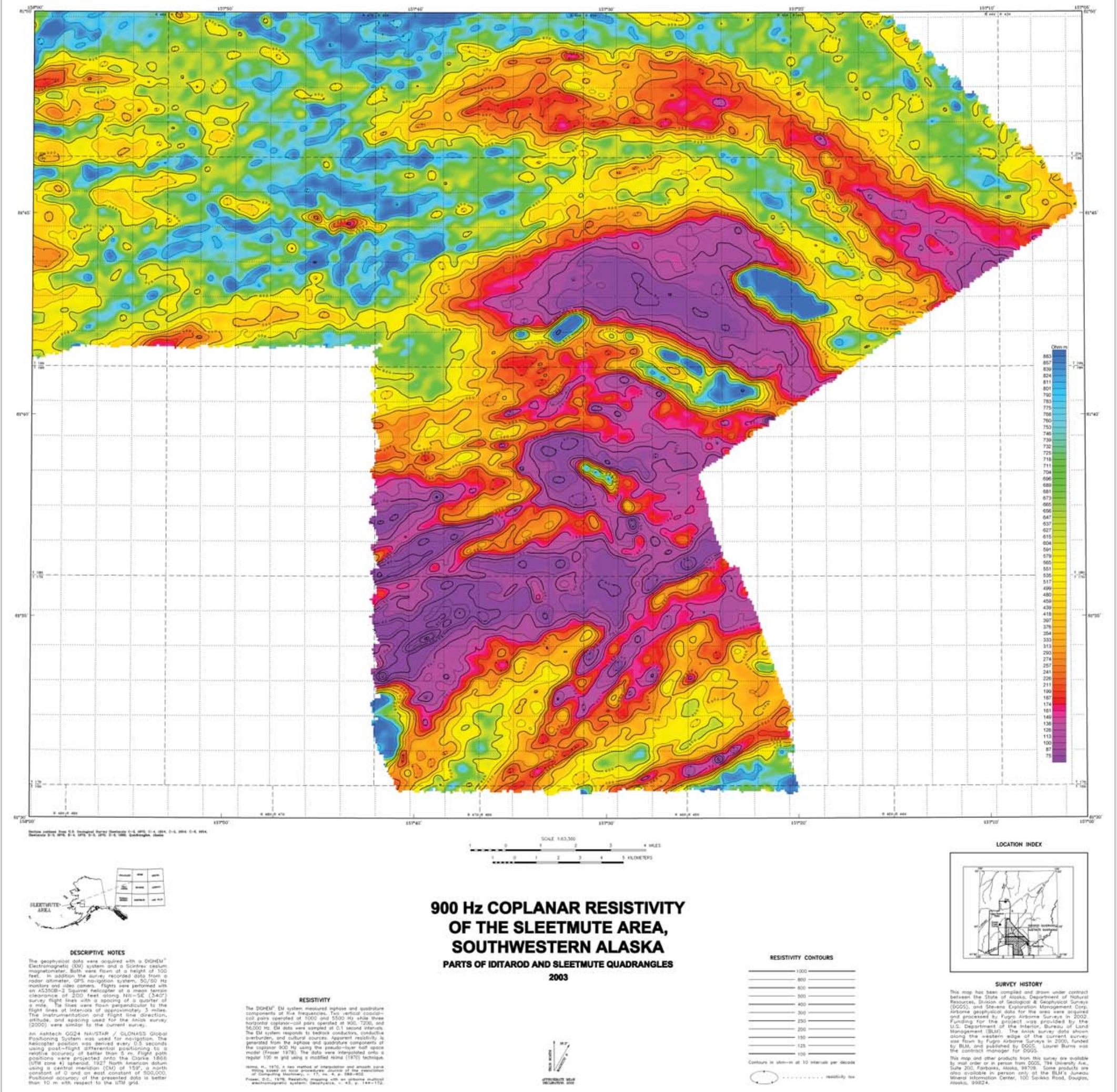




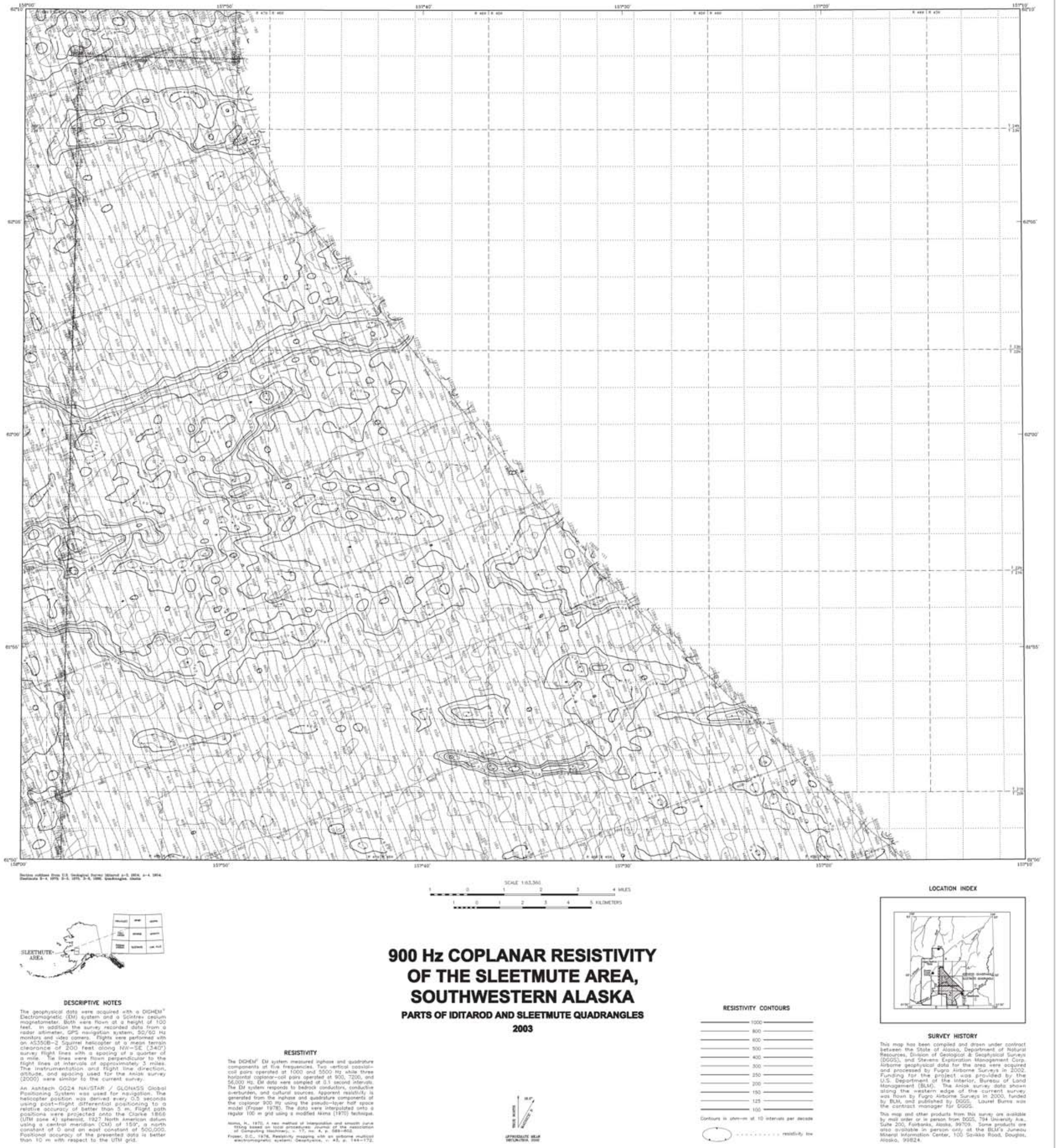




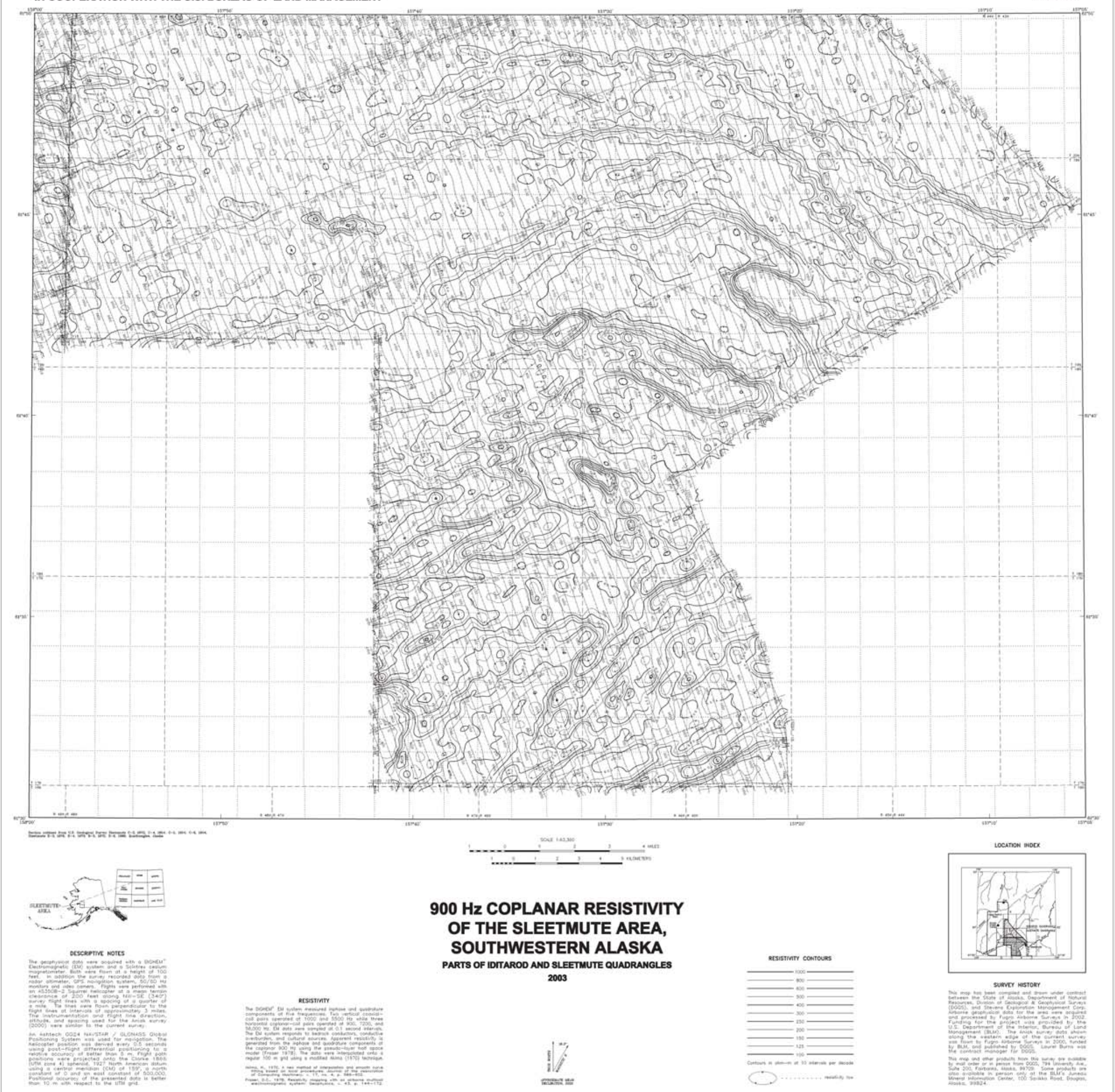




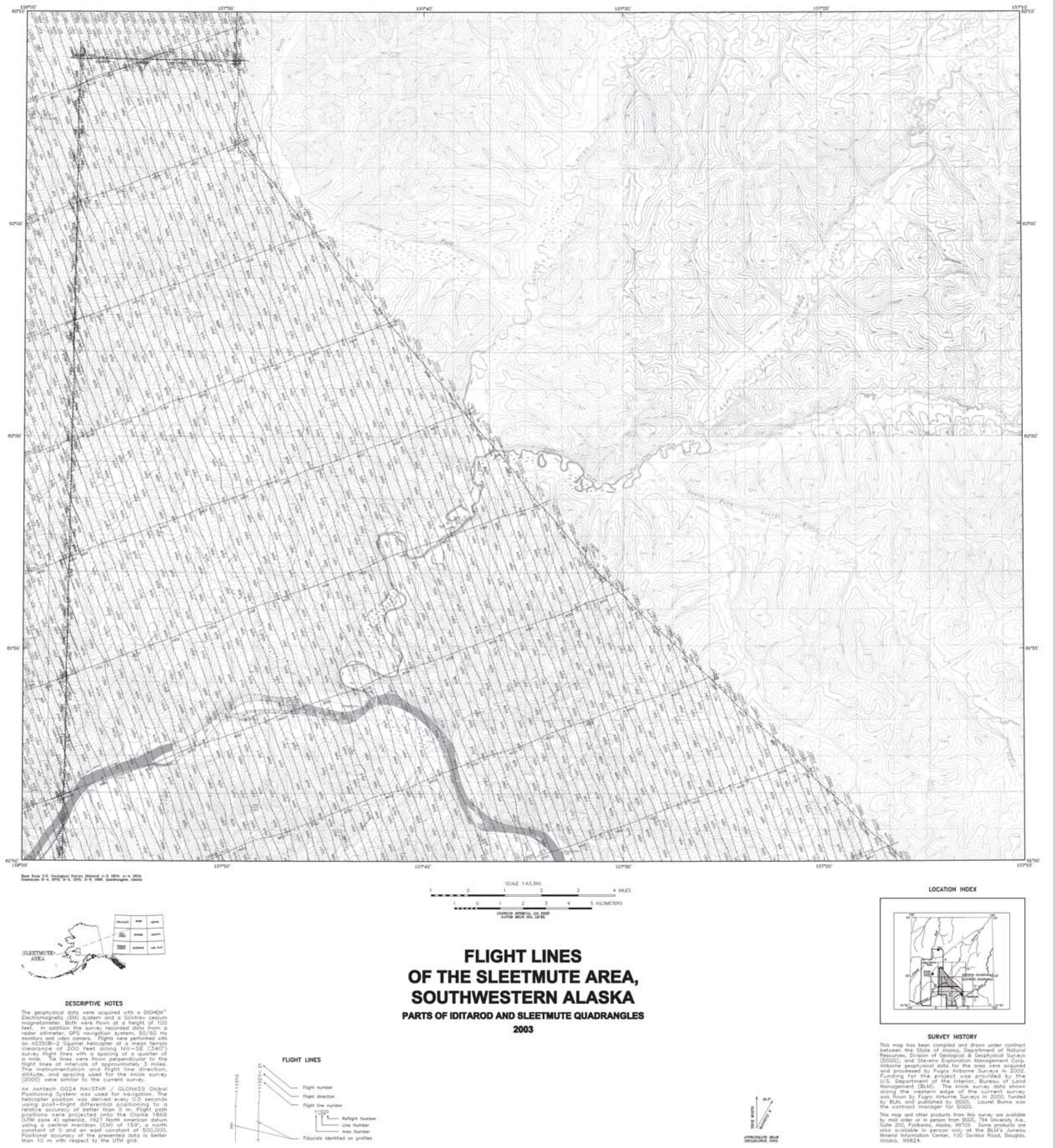




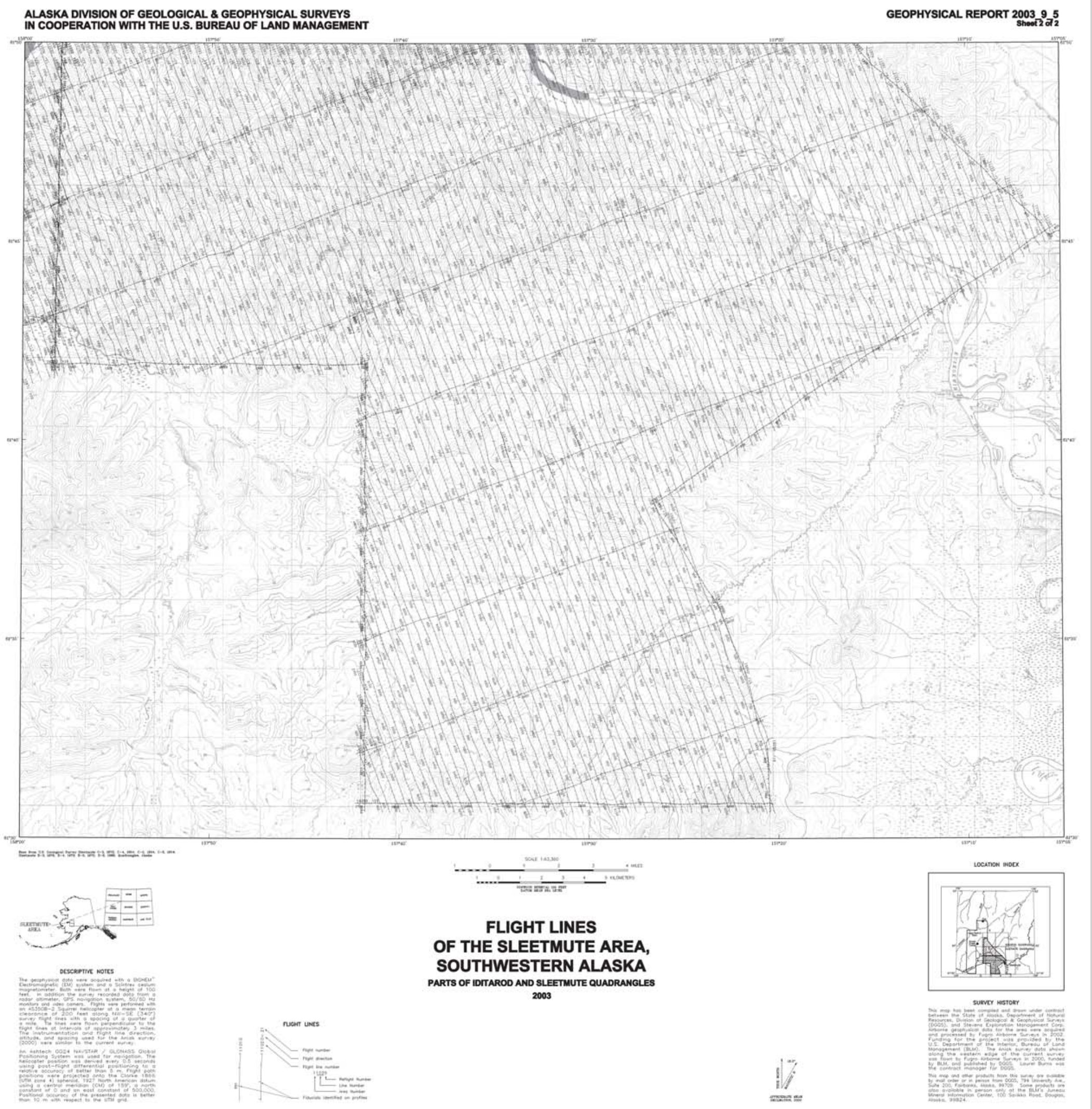




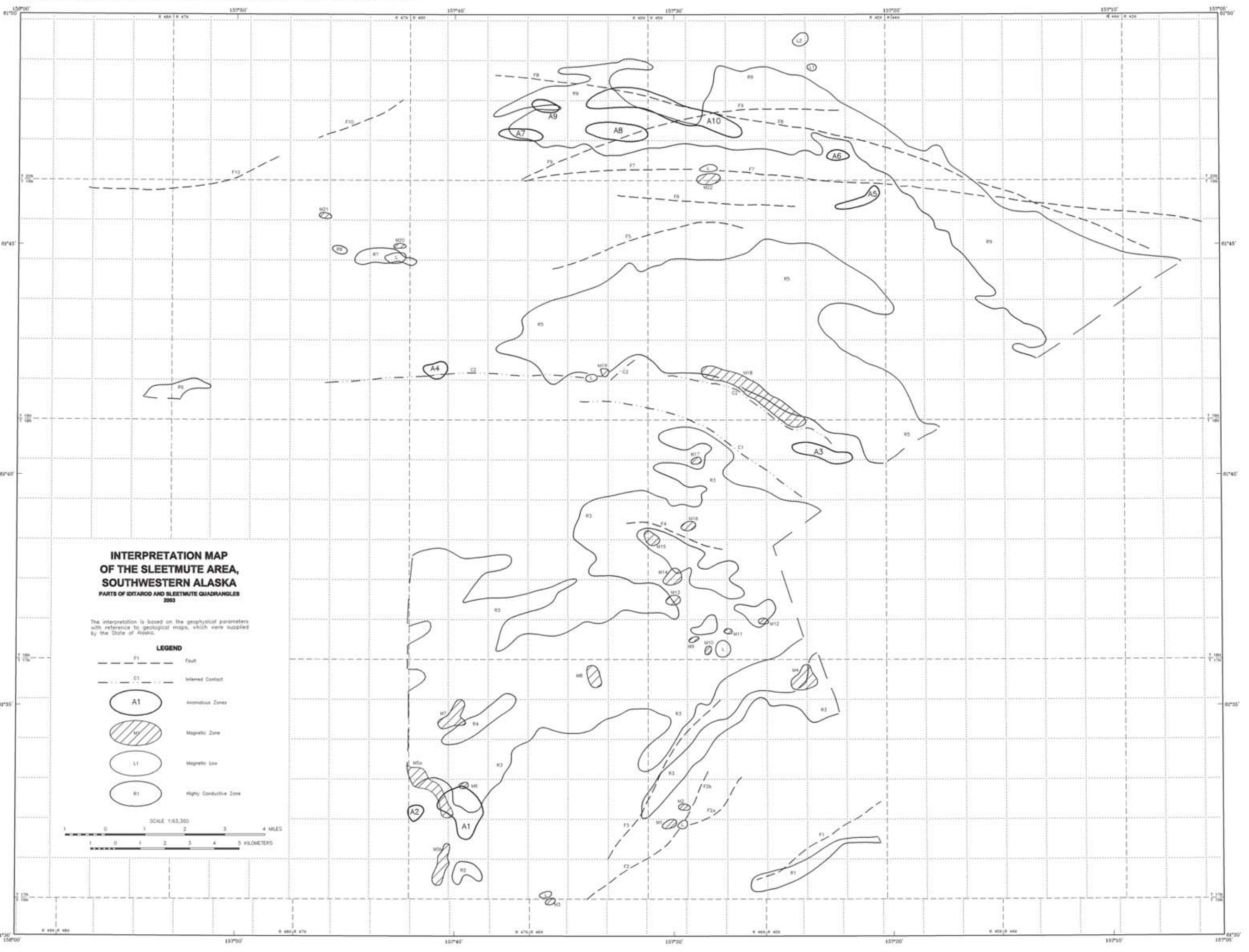

